NBER WORKING PAPER SERIES

\title{
BANK QUALITY, JUDICIAL EFFICIENCY AND BORROWER RUNS: LOAN REPAYMENT DELAYS IN ITALY
}

\author{
Fabio Schiantarelli \\ Massimiliano Stacchini \\ Philip E. Strahan \\ Working Paper 22034 \\ http://www.nber.org/papers/w22034 \\ NATIONAL BUREAU OF ECONOMIC RESEARCH \\ 1050 Massachusetts Avenue \\ Cambridge, MA 02138 \\ February 2016
}

The views expressed in this paper are those of the authors alone and do not necessarily represent those of the institutions with which they are affiliated, nor of the National Bureau of Economic Research. We are grateful to Massimiliano Affinito, Giorgio Albareto, Alberto Alesina, Francesco Columba, Riccardo De Bonis, Emilia Bonaccorsi di Patti, Francesco Giavazzi, Francesco Manaresi, Alfonso Rosolia and seminar participants at the Bank of Italy, Bocconi University, Boston College, University of Chicago, Georgia Tech, the University of Illinois at Champaign-Urbana, Notre Dame, Nova School of Business, the Bank of Portugal, SAIF, Tsinghua University and the University of Western Ontario for helpful comments. We also thank Ana Lariau Bolentini and Danilo Liberati for the helpful research assistance.

NBER working papers are circulated for discussion and comment purposes. They have not been peer-reviewed or been subject to the review by the NBER Board of Directors that accompanies official NBER publications.

(C) 2016 by Fabio Schiantarelli, Massimiliano Stacchini, and Philip E. Strahan. All rights reserved. Short sections of text, not to exceed two paragraphs, may be quoted without explicit permission provided that full credit, including $(\odot$ notice, is given to the source. 
Bank Quality, Judicial Efficiency and Borrower Runs: Loan Repayment Delays in Italy Fabio Schiantarelli, Massimiliano Stacchini, and Philip E. Strahan

NBER Working Paper No. 22034

February 2016, Revised August 2016

JEL No. G02

\begin{abstract}
Exposure to liquidity risk makes banks vulnerable to runs from both depositors and from wholesale, short-term investors. This paper shows empirically that banks are also vulnerable to run-like behavior from borrowers who delay their loan repayments (default). Firms in Italy defaulted more against banks with high levels of past losses. We control for borrower fundamentals with firm-quarter fixed effects; thus, identification comes from a firm's choice to default against one bank versus another, depending upon their health. This 'selective' default increases where legal enforcement is weak. Poor enforcement thus can create a systematic loan risk by encouraging borrowers to default en masse once the continuation value of their bank relationships comes into doubt.
\end{abstract}

Fabio Schiantarelli

Department of Economics

Boston College

140 Commonwealth Avenue

Chestnut Hill, MA 02467

and IZA

schianta@bc.edu
Philip E. Strahan

Carroll School of Management

324B Fulton Hall

Boston College

Chestnut Hill, MA 02467

and NBER

philip.strahan@bc.edu

Massimiliano Stacchini

Bank of Italy

via Nazionale 91, 00184

Roma, Italy

massimiliano.stacchini@bancaditalia.it 


\title{
Bank Quality, Judicial Efficiency and Borrower Runs:
}

\section{Loan Repayment Delays in Italy}

\author{
Fabio Schiantarelli, Massimiliano Stacchini ${ }^{\dagger}$ Philip E. Strahan ${ }^{\ddagger}$
}

August 2016

\begin{abstract}
Exposure to liquidity risk makes banks vulnerable to runs from both depositors and from wholesale, short-term investors. This paper shows empirically that banks are also vulnerable to run-like behavior from borrowers who delay their loan repayments (default). Firms in Italy defaulted more against banks with high levels of past losses. We control for borrower fundamentals with firm-quarter fixed effects; thus, identification comes from a firm's choice to default against one bank versus another, depending upon their health. This 'selective' default increases where legal enforcement is weak. Poor enforcement thus can create a systematic loan risk by encouraging borrowers to default en masse once the continuation value of their bank relationships comes into doubt.
\end{abstract}

\section{Introduction $^{1}$}

Under the traditional view of Diamond and Dybvig [1983], provision of liquidity insurance to households and firms exposes banks to the risk of a destructive run: depositors may demand

${ }^{*}$ Boston College and IZA

${ }^{\dagger}$ Bank of Italy

‡Boston College \& NBER

${ }^{1}$ The views expressed in this paper are those of the authors alone and do not necessarily represent those of the institutions with which they are affiliated. We are grateful to Massimiliano Affinito, Giorgio Albareto, Alberto Alesina, Francesco Columba, Riccardo De Bonis, Emilia Bonaccorsi di Patti, Francesco Giavazzi, Francesco Manaresi, Alfonso Rosolia and seminar participants at the Bank of Italy, Bocconi University, Boston College, University of Chicago, Georgia Tech, the University of Illinois at Champaign-Urbana, Notre Dame, Nova School of Business, the Bank of Portugal, SAIF, Tsinghua University and the University of Western Ontario for helpful comments. We also thank Ana Lariau Bolentini and Danilo Liberati for the helpful research assistance. 
cash solely because they expect others to do the same. In the aftermath of the financial and sovereign debt crises, these old-style depositor runs have been the exception rather than the rule. $^{2}$ But even in these modern crises, we have seen panic-motivated instances of drying up of wholesale, short-term debt markets, and increases in collateral demands in asset-backed commercial paper and repo markets. ${ }^{3}$ These episodes, often called 'runs on the shadow banking system in the US', create similar pressures on banks as traditional depositor runs, making it hard for them to fund new loans and raising the likelihood that fire sales of old ones can cause insolvency. Similar liquidity pressures from the asset-side of banking emerged following the collapse of Lehman, as firms drew down credit lines at banks perceived to be more likely to restrict access to future liquidity. ${ }^{4}$

Both the traditional literature as well as recent studies of financial crises emphasize liquidity as the key risk that makes banks uniquely vulnerable. This framework rationalizes a host of government interventions such as deposit insurance schemes and lenders of last resort, as well as necessary but potentially distortive regulations on bank risk taking, capital structure and liquidity exposure (e.g. Basel I, II and III).

In this paper, we show that banks face a second source of vulnerability, one stemming from borrowers rather than from demanders of liquidity. Using data from Italy leading up to and following the Euro crisis, we provide evidence that bank instability can stem from credit risk. The link between credit risk and bank stability is well known: history tells us that waves of bank failures are often traceable to borrower losses and declines in the value of loans. ${ }^{5}$ However, we highlight a new channel through which credit risk enhances bank fragility. We show that borrowers selectively default against banks already weakened by past bad loans; borrowers thus seem to default because they observe other borrowers doing so.

\footnotetext{
${ }^{2}$ Exceptions include the withdrawals of deposits from Northern Rock at the beginning of the financial crisis, and the more recent withdrawals of deposits from Greek banks during the negotiations with their creditors.

${ }^{3}$ See Freixas, Laeven, and Peydro [2015] and Gorton and Metrick [2012].

${ }^{4}$ See Ivashina and Scharfstein [2010], Cornett et al. [2011], and Ippolito et al. [2015].

${ }^{5}$ The principles for appropriate management of credit risk are also a long-lasting topic of debate for regulators (e.g Basel I, II, III).
} 
Our results emphasize the importance of legal enforcement in mitigating this problem, as the magnitude of these 'borrower runs' increases in areas of Italy where legal disputes take longer to resolve. ${ }^{6}$

Our data allow us to capture a firm's decision to delay repayments of term loans as well as draw-downs of lines of credit in excess of the maximum borrowing limit at the level of the bank-borrower. Obviously, there can be multiple causes for a delay in loan repayments, ranging from firm financial distress to strategic considerations by firms about how such behavior may affect their ongoing or future relationship with lenders. With regard to the latter, a firm will be trading off the short-term gain of keeping control of financial resources (i.e. by not paying now), against the potential future loss of impairing their relationship with the current lender(s) or with potential future lender(s). The balance of this tradeoff may depend on the financial health of the lender, on the bargaining power of the borrower, and on the institutional environment that affects the ex post ability to recover collateral or otherwise force repayment through the judicial process. Everything else equal, one would expect a firm to be more likely to delay re-payment to weaker banks because the expected value of the continuation of the relationship is smaller. Firms with greater bargaining power - which we proxy by firm size - also ought to be more willing to default when lenders are weak, either because lenders will be reluctant to cut off a large customer or because large firms have better ability to switch lenders. Finally, firms will be more willing to delay loan repayment the harder it is for lenders to recover their interests through the courts.

Our evidence supports these predictions. We exploit a unique data set, the Italian Credit Register, that contains detailed information on all bank loans above 30,000 Euros given to firms. The data include information on repayment delays and the degree of impairment of loans, including those that fall short of being formally classified as "bad" by the bank. The solvency of Italian firms and the quality of loans has been strongly affected by the double

\footnotetext{
${ }^{6}$ In fact, reform of the Italian legal system has been a focus of recent efforts to help stimulate better economic performance. The Wall Street Journal reports that, "The snail's pace of Italy's courts throws sand into the wheels of the economy in myriad ways. Banks struggle to resolve bad loans because bringing deadbeat debtors to court takes by far the longest in Europe." [Zempano, 2014]
} 
dip recession following the global financial crisis of 2007-08 and the sovereign debt crisis of $2010-11 .^{7}$

We match these data to individual balance sheets of banks reported to the Bank of Italy, which is in charge of financial supervision, as well as with borrower balance-sheet data collected by the Balance Sheet Register (these data have been provided by lenders for information-sharing purposes since 1983). The data can also be matched to measures of local judicial (in)efficiency in recovering the collateralized assets estimated by an index based on Italian Ministry of Justice data. ${ }^{8}$ While civil law and procedures are formally the same across the national territory in Italy, the real-world effectiveness of the court system varies widely, depending upon local jurisdictional court proceedings (Carmignani and Giacomelli, 2009; Giacomelli and Menon, 2013). We exploit this regional and sub-regional variation to test for the importance of legal enforcement on default behavior.

As in other studies, we exploit the fact that many Italian firms borrow from multiple banks. This feature allows us to introduce firm-specific, time-varying effects to fully absorb firm-level fundamentals that may determine the decision to delay loan repayment. Our identification thus comes solely from variation in bank characteristics, characteristics of the bank-firm relationship, and, importantly, on the efficiency of the court system. In other words, we test how the same firm behaves with respect to different banks, depending upon the strength of the bank's balance sheet, the local judicial environment, and the nature of the past bank-firm relationship.

The results suggest that bank balance sheet strength - particularly past bad loans play an important role in determining the probability of a delay in loan repayment. In our basic specification, the stock of past bad loans increases the probability of borrower default. The result implies that, on average, banks with weaker balance sheets due to past (and non-collectable) bad loans experience more future defaults (in the form of temporary

\footnotetext{
${ }^{7}$ In seven years, manufacturing firms lost $17 \%$ of its productive capacity and net job destruction reached almost one million.

${ }^{8}$ The data are downloadable from the web page of the Italian Ministry of Justice. See https: //reportistica.dgstat.giustizia.it/
} 
delays in repayment, many of which ultimately become permanently impaired). That is, we observe borrowers running on weak banks. The results hold when we allow the effect to differ according to firm size: in this case the (absolute) value of the coefficient increases in firm size, suggesting that larger firms, presumably the ones with greater bargaining power, tend to be those most likely to delay payment.

When we allow the degree of local judicial efficiency to interact with bank health (its direct effect is absorbed by the fixed effects), we find that the impact of bad loans becomes significantly larger where the courts are less efficient. This makes sense because a lower probability of recovery of principal interest through weak courts reduces the cost to borrowers of delaying repayments. In fact, we find no effect of past bad loans on current default in provinces where legal enforcement is strong. Thus, our results suggest that 'borrower runs' only occur when two conditions hold simultaneously: first, the lender itself is weakened from past losses and thus less able to commit to extending future credit; second, the lender's ability to enforce contracts ex post is also weak due to poor legal enforcement. In our last set of tests, we stratify firms by risk to test whether or not the behavior we document truly reflects strategic default. Are distressed borrowers merely selecting which banks to pay by allocating a fixed but limited cash-flow budget across lenders? Or, are borrowers paying less than they otherwise would because lenders are weak? In fact, we show that even the safest firms exhibit this behavior. Even firms that could pay - those with high credit quality - sometimes choose not to pay because of the confluence of weak banks and weak legal enforcement.

Our result suggests a strong policy implication: improving banks' ex post ability to enforce contracts in court removes the possibility of a potential bad equilibrium in which the aggregate level of default is higher than would otherwise occur due to firms defaulting strategically. The result supports recent efforts on legal reform, which have been driven by the scale of bad loans in Italy. In December of 2015, for example, bad loans summed to about $€ 200$ billion, a large figure that represents approximately $11.0 \%$ of the total amount 
of loans given (18\% including other troubled loans not written off). Unlike other recent banking problems, where losses were concentrated in real estate or sovereign debt exposure, close to $80 \%$ of these bad debts came from bank lending to non-financial businesses, which is the focus of our tests. Concern over declines in credit quality has prompted recent reforms aimed at streamlining insolvency proceedings and speeding the process by which lenders can repossess collateral on defaulted loans. According to our paper, legal reforms to improve the efficiency of the courts, and in particular to speed up the judicial or extrajudicial recovery of collateral, offer the potential of substantial benefits for Italy's banks (and, by extension, the economy itself), without any moral hazard downside.

The structure of the paper is as follows. In Section 2 we will review briefly the theoretical and empirical literature on borrower runs and discuss our contribution. In Section 3 we will describe the data we use in our empirical analysis and outline the growing importance for the Italian banking system of delayed loan repayment and bad loans generally. Section 4 contains a description of our identification strategy, econometric methods and empirical results. Section 5 concludes.

\section{Literature Review}

How does our contribution relate to the previous literature? Theoretical contributions suggest that borrower runs are possible. Using a global games framework, Bond and Rai [2009] prove the existence of multiple equilibria in loan repayment behavior. ${ }^{9}$ The crucial tradeoff for borrowers is represented by the present benefit of default vs. the expected loss of future access to credit conditional on default. The expected value of future access to credit depends upon the likelihood that other borrowers will repay their loans, as this affects banks' lending ability. This externality can lead to outcomes in which a borrower defaults because she expects others to do so. Carrasco and Salgado [2014] model borrower runs in the context

\footnotetext{
${ }^{9}$ On global games see, for instance, Morris and Shin [2001].
} 
of a costly state verification model. ${ }^{10}$ Equilibria with partial or complete default emerge in this case as the result of banks' limited resources in auditing borrowers, resulting in a reduction in the incentive for them to repay when defaults are expected to be high across many borrowers.

In both these theoretical frameworks, bank financial health mitigates the probability of a borrower run. But there is no empirical evidence to our knowledge that a borrower's decision to pay or not pay depends on the health or solvency of its bank, or on the default behavior of other borrowers. Our empirical work focuses primarily on indicators of bank health such as capitalization, asset composition, past bad loans, stability of funding, size, and profitability. Obviously the probability of default will depend critically on borrower fundamentals. To isolate the effect of bank fundamentals, we study firms that borrow from more than one lender, and we control for firm specific and time varying factors that affect a firm's repayment capacity (either actual or expected).

Beyond bank health, theory suggests that the occurrence of a borrower run will depend upon the institutional environment in which contracting takes place. In particular, the ability of creditors to recover the money lent will mitigate the incentive to delay repayment. Hence, we study the effects of efficiency of the local courts as a determinant of the decision to delay repayment. ${ }^{11}$ Since La Porta et al. [1997] and La Porta et al. [1998], financial economists have emphasized the importance of legal contract enforcement in shaping financial relationships. Many of the empirical studies emphasize how measures of enforcement affect ex ante contract terms such as ownership of debt and equity, the use of collateral and covenants in debt contracts, and the availability and price of credit (see Roberts and Sufi [2009] for a survey of the empirical literature). Djankov et al. [2003] show that civil-law countries like Italy tend to have greater legal formalism and experience longer delays in resolving commercial disputes (collecting on bad checks or evicting non-paying tenants) compared to common

\footnotetext{
${ }^{10}$ See Gale and Hellwig [1985] and Townsend [1979].

${ }^{11}$ In a costly state verification model, for instance, court efficiency will be reflected in and captured by the monitoring/auditing cost parameter.
} 
law countries. Jappelli et al. [2005] study Italy, as we do, and show that credit is more available and at lower prices in regions with better enforcement in court. A number of other studies use changes in bankruptcy laws, mechanisms, or regulations as exogenous shocks to enforcement costs to trace out the effects on credit supply. For example, Scott and Smith [1986] find that increased debtor protection following the 1978 bankruptcy reform in the US, and hence weaker enforcement, was followed by an increase in interest rates on loans to small borrowers. Fedaseyeu [2015] exploits changes in state regulation of debt collectors an important enforcement mechanism outside bankruptcy - and finds that credit supply to high-risk borrowers increases with less restrictive regulation of the debt collection business. Gropp et al. [1997] show that reductions in enforcement from state-level variation in the amount that individuals can shield in bankruptcy from their creditors via the homestead exemption both constrains credit supply and increases credit demand.

A number of recent studies have found that credit supply by distressed banks was constrained in Italy during both the 2007-2008 global financial crisis as well as the more recent Euro crisis (e.g. Albertazzi and Marchetti, 2010;Bolton et al., 2013; and Bofondi et al., 2013). In addition, bank distress stemming from exposure to risky sovereign debt reduced credit supply and helped propagate the Euro crisis from distressed to non-distressed countries across the Euro system (e.g. Popov and van Horen [2013], Marco [2015]). ${ }^{12}$ Our study helps rationalize this behavior, as we show that past distress raises the risk of future firm's default (even holding constant borrower fundamentals); hence, it makes sense that distressed banks would raise the price and restrict access to credit when extending new loans.

As far as we know there is no empirical evidence of borrower runs motivated by concern about bank loan losses or insolvency. Ivashina and Scharfstein [2010] do provide evidence that US firms drew more on their credit lines with banks that had a relationship with Lehman, but the mechanism they emphasize stems not from borrower unwillingness to re-pay their debt (our mechanism), but instead from borrower concern that liquidity would not be available

\footnotetext{
${ }^{12}$ On the real consequences of credit supply shocks in Italy see Cingano et al. [2013] and Balduzzi et al. [2014].
} 
in the future for the lending bank, leading to increased drawdowns on existing credit lines. Similarly, Ippolito et al. [2015] show that Italian firms with multiple credit lines drew more from banks that had higher pre-crisis exposure to the interbank market and thereby were more liquidity constrained. Their paper emphasizes the traditional source of bank instability: liquidity risk. Trautmann and Vlahu [2013] provides experimental evidence that solvent borrowers may be more likely to default strategically when their bank's expected strength is low and when their own expected repayment capacity is low. Survey-based evidence of strategic behavior by US households in mortgage markets has been provided in Guiso et al. [2013a]. They find that the propensity to default by households, even if solvent, is affected by both pecuniary and non-pecuniary factors such as views of fairness and morality. It is also related to the exposure to other people who have strategically defaulted.

We share with Ippolito et al. [2015] the focus on Italian firms and the use of the Italian Credit Register. Our emphasis, however, is on a different form of runs, one that stems from the credit-risk side of the business - delayed loan repayment - and that is motivated by concern about a bank's viability and ability to extend credit itself in the medium term, as opposed to having short term funding issues. Moreover, our contribution provides evidence on the key role of the courts as a determinant of the likelihood of borrower runs, in addition to firm size and the nature of the previous bank-firm relationship. The inefficiency of the court system in Italy is a very important policy issue affecting Italy's economic performance in many dimensions. ${ }^{13}$

\footnotetext{
13،The complex regulatory system, the relative inefficiency of public procedures and government action, the slowness of the justice system [...] all hinder the reallocation of productive resources to the most efficient firms, which is one of the main mechanisms of productivity growth. [...]The large stock of non-performing loans also reflects the very long and variable duration of insolvency and credit recovery procedures, due in turn to the country's cumbersome civil justice system. These widespread inefficiencies depress potential buyers' valuations of impaired assets and discourage their sale on the market" (Ignazio Visco, Governor's Concluding Remarks, Bank of Italy, 2015a).
} 


\section{Data Description}

To estimate our model we need information about the (ex post) performance of bank loans extended to non-financial corporations, the financial health of their lenders (banks), the efficiency of the judicial system, and characteristics of borrowers as well as the type of lending relationship they have with their banks. Our dataset thus combines four sources of information existing in Italy: (i) the Balance Sheet Register; (ii) the Credit Register; (iii) measures on the functioning of the judicial system estimated from data provided by the Ministry of Justice; and, (iv) the Bank of Italy's Supervisory Reports.

The Balance Sheet Register provides our sample of non-financial firms. It consists of around 32,000 industrial firms, 99\% of which are unlisted. The Register accounts for more than $70 \%$ of industrial sector value added over the fiscal years 2008-13. The Balance Sheet Register is a proprietary database set up and managed by Cerved SPA, using data deposited by firms at the local Chambers of Commerce, as required by Italian law. ${ }^{14}$ Data from the Balance Sheet Register have been used extensively since 1983 by both lenders to assess firm soundness as well as by scholars to investigate various research questions.

The Credit Register, an archive maintained by the Bank of Italy, provides lender-borrower level data on characteristics of loans extended by banks operating in Italy. The data include information on loan type (credit lines, term loans), size, maturity, the pledging of real collateral, personal guarantees, accounts receivable, and ex post performance. Loans are reported when tranches exceed Euro 30,000 by the entire population of credit institutions. Hence we capture all but the very smallest firms borrowing from banks.

We use data from the Ministry of Justice to build a measure of enforcement for creditors based on the length of legal proceedings across Italy. Specifically, we use court-level data on the mean time to resolve matters regarding the execution of property. Following Carmignani and Giacomelli [2009] and Giacomelli and Menon [2013], we apply the formula adopted by the Italian Ministry of Justice and the Italian National Institute of Statistics (Istat) to

\footnotetext{
${ }^{14}$ Cerved is a member of the European Committee of Central Balance-Sheet Data Offices.
} 
calculate the court-level indicators on the length of proceedings in 2007. The length of court proceedings is an inverse measure of efficiency (or a measure of inefficiency). We apply the following formula to the "flow" data disseminated by the Ministry of Justice:

$$
D_{t}=\frac{P_{t}+P_{t+1}}{E_{t}+F_{t}}
$$

where $D_{t}$ is time to resolve matters regarding the execution property in years, $P_{t}$ are pending cases at the beginning of 2007, $F_{t}$ are new cases filed during 2007 and $E_{t}$ are cases ending with a judicial decisions or withdrawn by the parties during 2007 . We are careful to measure judicial efficiency before the onset of the banking losses that began in the wake of the Euro crisis (and before the beginning of our sample in 2008). Measured this way, we avoid reverse causality whereby a high level of distressed loans, by clogging up the courts, leads to an increase in the measure of judicial inefficiency.

In assigning each loan contract to a judicial jurisdiction, we use the judicial court located where the bank owning the branch has its legal residence. This choice is motivated by the fact that, in loan contracts, banks usually indicate the judicial court where the bank has its legal residence as the one that will be in charge in case of legal disputes with the borrowing firm. Ex post enforcement, however, requires several steps. First, lenders need an injunction from the court typically located in the province of its head office. Having gotten an injunction, to take possession of collateral the lender then must adjudicate before the court in the location of the collateral, which is likely, but not certain, to coincide with the firm's location. The latter, in turn, may or may not coincide with the legal location of the bank. Thus, legal enforcement in two provinces may matter. Since the process always begins in the bank's province, we report most of our models using legal enforcement measured in the province of lender's head office. The time to get an injunction or to recover the collateral are highly correlated and conclusions are, therefore, insensitive to this choice. ${ }^{15}$ We present

\footnotetext{
${ }^{15}$ The correlation between the variable on the length of the first part of the judicial process ("Processi di Cognizione Ordinaria") and that for the proceedings of property executions is close to 0.7.
} 
results using the latter measure, but we also report a robustness test in which we remove any ambiguity about legal efficiency by including only observations in which the lender and borrower reside in the same province.

Finally, we obtain bank balance sheet data from the Supervisory Reports collected by the Bank of Italy, which is in charge of banking supervision in Italy. We use aggregate data for banks belonging to banking groups or holdings, and individual data for stand-alone banks, as we want to avoid measurement errors in our bank quality indicators due to infra-group reallocations of resources. ${ }^{16}$

\subsection{Some facts on loan quality, bank quality and judicial efficiency in Italy}

The formal classification of problematic loans adopted by Italian banks is ample and includes four categories: (i) "Past due/overdrawn more than 90 days", (ii) "substandard loans", (iii) "restructured exposures" and (iv) "bad loans." "Past due/overdrawn by more than 90 days" are exposures (other than those classified as bad loans, substandard or restructured) whose repayments have been delayed by the borrowers for more than 90 days on a continuous basis. "Substandard loans" are exposures to counterparties which face temporary difficulties expected to be overcome within a reasonable period of time. Specifically, this class includes two subsets of problematic loans: the first one includes loans which are "objectively" substandard, such as loans or credit lines which are past due or overdrawn; the second group includes loans classified by the lender as "substandard" according to a judgmental basis only, meaning without any formal loan repayment delays to the bank in question or overdrawing on existing credit lines. This judgment could also depend upon a delay in payments to other lenders. "Restructured loans" are exposures in which lenders, as a result of the deterioration of the borrower's financial situation, agree to change the original conditions, giving rise to

\footnotetext{
${ }^{16}$ Data on branches of foreign banks operating in Italy have been discarded from the dataset, as aggregate data are not available for holdings which are headquartered outside Italy.
} 
a loss for the creditor. Finally, the "bad loans" category includes exposures to insolvent counterparties (even if not legally ascertained), regardless of any loss estimate made by the bank and irrespective of any possible collateral or guarantee. ${ }^{17}$

Table 1a shows the relative importance of these four categories and how they have evolved over time during our sample. Loans were broadly performing well before the 2007-09 financial crisis: the share of performing loans exceeds $98 \%$ in 2006-2008. The quality of lending began to worsen in 2009 (96\% performing), and then fell in each year through 2014, i.e. after the 2007-09 financial crisis and especially after the sovereign debt crisis, which was accompanied by a worsening of the real performance of the Italian economy. ${ }^{18}$

In Table 1b we report the transition matrix (looking ahead one year) for all the borrowers in Italy based on data on loan quality published by the Bank of Italy. ${ }^{19}$ These data indicate that in the first part of the sampled period around half of loans past due or overdrawn become performing again. However, after the sovereign debt crisis many of them eventually end up in the bad-loan category. For example, as of 2009, $51 \%$ of late or overdrawn loans were performing one year later. In contrast, this probability falls to just $27 \%$ by the end of 2013. During the latter years, the typical scenario for a loan would be to move first from the

\footnotetext{
${ }^{17}$ As of September 2014, non-performing exposures are classified according to definitions established by the European Banking Authority. The new definitions, to be used for harmonized supervisory financial reporting across Europe, are basically in line with those that were in force in Italy before the break and that were used by banks to classify the quality of the loans we analyze in this paper.

${ }^{18}$ The large volume of bad loans also reflects constraints and rigidities that oblige Italian banks to keep impaired assets on their books much longer than banks in other main countries. Among others, the unfavorable tax treatment of write offs as well as the length of bankruptcy procedures limit the incentives for banks to sell problematic loans and restrain the development of a large secondary market for these assets. On this accounts, in May 2015, the Italian Government has taken measures to make loan losses immediately tax deductible. Incentives for developing the market in non-performing loans could also come from: (i) legislative measures adopted by the Government in 2015 and 2016 to shorten credit recovery times and align them with international best practices; (ii) the state guarantee scheme offered at market conditions for senior tranches of securitized bad debts (following an agreement reached with the European Commission); (iii) the investments of Atlante, a private fund that can operate on the riskiest securitization tranches.

${ }^{19}$ Table $1 b$ reports a transition matrix, which is based on the data published in the Bank of Italy's Annual report. Data refer to the universe of banks and financial intermediaries operating in Italy and to the population of non-financial companies recorded in the Register (see Bank of Italy [2015b],Table A6.15, page 56, Banche e società finanziarie: matrici di transizione tra classi di anomalia nel rimborso dei prestiti). Transitions are obtained by comparing the classification of a single borrower, at the beginning and at the end of the observation periods, across the loan quality classes as they are defined in the methodological appendix to the table (see page 197).
} 
late category to the substandard category (probability $>40 \%$ ) and then to transition from substandard to the bad loans category (probability around 25\%). As the transition matrix shows, once a loan goes bad, it stays bad ("bad loans" is effectively an absorbing state).

The key outcome variable of this study is intended to measure a borrower's decision to delay repayment to its bank. As such, we construct late payment as an indicator that equals one if the firm has a loan with a bank classified as 'past due/overdrawn', or 'objective (past due/overdrawn) substandard', and equal to zero if the loan is 'performing'. We focus on the initial phase of the process of the loan quality deterioration because we want to avoid measurement errors when we capture the firm's decision to default: in particular we want to capture, as much as possible, a firm's decision to delay its payments. Therefore, we discard the "judgmental" component of "substandard loans", which are based on the subjective choice of the lender, and "restructured loans", which depend upon a bargaining between the bank and the firm. We also discard in our dependent variable those loans classified as "bad loans", which reflect a bank's final determination that the loan will not be repaid.

Table 1a and Figure 1 show the development of late payment - our dependent variable - over time. The share of loans in default increases almost monotonically, starting in 2009. A similar development - even if the share of default is slightly lower - is observed when we exclude credit lines from the ratio and consider the aggregate, which includes term loans only.

The empirical model, spelled out in the next section explicitly, links borrower default to measures of bank characteristics, including a measure of bank losses associated with changes in the value of the sovereign bonds. See the Data Appendix for a description of the variables and their data sources.

Table 2 reports basic summary statistics on the characteristics of banks during our sample (2008-2013). Most variables are available at quarterly frequency. The profit variable is reported, however, only at a bi-annual frequency, so we present results with and without this variable. Our key measure of bank health - bad loans / total assets - varies substantially, 
reflecting both changes across time (as in Figure 1), as well as substantial variation in the cross section. We also capture liquidity-risk exposure of banks in two ways, one from each side of the balance sheet. Italian lenders rely strongly on stable sources of funding, i.e. deposits from residents and bank bonds held by households, which account for around $60 \%$ of their balance sheets. Stable funding also varies dramatically across the sample, with some banks having around $90 \%$ stable funds and others relying mainly on other sources of funds, such as, inter alia, short-term wholesale funds. For asset liquidity, we again observe substantial variation, with the share of assets in bonds and cash varying from $5 \%$ to almost half of the balance sheet. We also control for lender size. As in most countries, most of the 695 banks employed in this study are small, with a median asset size of 430 million Euro, but the largest banks have over 200 billion Euro in total assets.

Table 3 reports statistics on the borrowers. The median firm has about 50 employees and 14 million Euros in assets. Leverage varies from around 2\% to around $60 \%$ of assets, with a median of about $30 \%$. Firm age averages 25 years. Overall, our sample is dominated by privately held, small and medium-sized firms. That said, our main results discussed below absorb with a quarter-firm dummy the direct effects of constant and time-varying firm characteristics to focus on bank effects on default.

As far as the efficiency of the judiciary in protecting creditors, Table 4 shows that the estimated average duration of the property execution proceedings was more than three years, equal to 1,189 days in Italy in 2007. However, significant disparities are observable across Italy, with the duration ranging from under one year for the Court of Crema to close seven years for that of Cosenza. Figure 2 shows a marked contrast between the areas of the northern and the southern parts of Italy, with the latter characterized by a significant higher length of the judicial proceedings. That said, heterogeneity exists across court jurisdictions operating within these two broad areas. For example, the estimated length of the proceedings in the Judicial Courts of Ragusa and Brindisi - both localized in the South - are equal to 3,336 and 1,137 days, respectively. 


\section{Econometric Methods and Results}

We estimate a linear probability model that links borrower payment delays to a set of bank effects, firm-time effects and measures of bank characteristics, as follows:

$$
y_{i, b, t}=\sum_{k=1}^{K} \alpha_{k} x_{b, t-1}+\theta_{i, t}+\delta_{b}+\varepsilon_{i, b, t}
$$

where $i$ denotes firm, $b$ denotes bank and $t$ denotes time (quarterly or bi-annual frequency). The outcome $y_{i, b, t}$ (late payment) equals an indicator variable set to 1 if the firm has a loan repayment delay or overdrawn with the bank in the quarter and 0 if loans granted by the bank to the firm are performing in the quarter. Explanatory variables $\left(x_{b, t-1}\right)$ are timevarying bank characteristics from the end of the previous period. We include the log of bank assets to capture bank size (lntot) and consider capitalization (cap), the amount of stable sources of funding (stable), liquid assets (liquidity) and ROE (profits) as bank-level covariates; to capture the strength of the (lending) relationship between the bank and the firm, we use the share of loans from bank $b$ to firm $i$ (bkshare).

Our main variable of interest is the ratio of past bad loans to total assets (badloans), a measure of bank health that captures the extent to which a bank has already experienced high levels of borrower default. We allow the effects of bad loans to vary according to the judicial efficiency of the local courts (measured by the log of the average length of property execution proceedings (inefflaw)), as well as by firm size (captured by indicators for small, medium-small, medium-large, and large firms by assets); we interact bad loans (as well as other bank co-variates) with each of these variables in some of our specifications. In our last set of tests, we report interactive models based on firm credit quality.

To absorb unobserved heterogeneity at the bank level, we control for bank fixed effects $\left(\delta_{b}\right)$. These effects capture time invariant components of managerial quality, the quality of governance, market structure, and so on. Moreover, our main variable of interest varies at the bank level over time, so we cluster standard errors at the bank level. The firm-time 
effects $\left(\theta_{i, t}\right)$ control non-parametrically for all characteristic of borrowers that might lead to default across all lenders, such as lack of investment opportunities or business fundamentals related to risk, poor cash flow or low profit realizations, as well as other hard-to-measure time-varying attributes that might be correlated with default. By absorbing these effects, we focus on a firm's decision as to which of its banks to pay and which not to pay. Identification comes only from firms which pay some of their banks but not others (in a given quarter). Any borrower paying all of its banks on time, or failing to pay all of its banks, is taken out by the firm-time effect. Thus, we can interpret the $\alpha_{k}$ coefficients as measures of 'selective' default - the extent to which a firm chooses to default, in the sense of not repaying the loan plus interest when it is due, with respect to one bank vs. another.

Our study rests on the assumption that borrowers pay attention to the quality of their banks' balance sheets, as it might influence lenders' ability to extend credit in the future. This is a very plausible assumption because bank balance sheet information is easily available and widely disseminated, including the information on loan quality. Moreover, as the problem of bad loans on banks balance sheet mounted, the national and international press have been focusing on credit quality as the main factor determining bank fragility. ${ }^{20}$

\subsection{Baseline result: Accumulated bad loans encourage firms to de- lay repayment (default)}

Table 5 reports our baseline specification with no interactive effects. As said, our sample covers the period 2008Q4-2013Q4; bi-annual data are used in regressions which include profits. These regressions focus strictly on the total effect of bank variables on firm's choice to delay loan repayment (i.e. to default). Columns (1)-(7) report the results for each bank characteristic one by one, and columns (8) and (9) report the multivariate models. Models with bank profits (columns (7) and (9)) have somewhat fewer than half of the observations because this variable is reported bi-annually, rather than quarterly.

\footnotetext{
${ }^{20}$ See, for instance, Pavesi [2015] or Legorano [2013].
} 
We find strong evidence that bank weakness leads firms to increase their willingness to default. Firms with more than one bank selectively default against the weaker one(s). Specifically, default is more likely at banks with high levels of past bad loans. These effects are large, both statistically and economically. For example, an increase in bad loans from the 25th to the 75 th percentile (a change of about 0.05 - see Table 2) is associated with an increase in default of 0.5 percentage points $(=0.05 \times 0.114$; see column $(8))$, which is large relative to the average default probability of about $3 \%$ (recall Table 1a). The effect is robust, entering the regressions with a similar magnitude irrespective of the specification or the sample (the sample drops by more than half when we include bank profit). The result suggests that extending credit can create bank instability, apart from the standard channel based on liquidity exposure: borrowers' tendency to default increases as they observe others doing so. This externality suggests the possibility of a bad equilibrium in which 'borrower runs' lead to bank distress and failure.

We also find some evidence, although less statistically robust, that banks with greater losses from sovereign exposure face higher levels of default (columns (6) and (8)). In addition, firms are more likely to default as their share of borrowing from a bank increases; this effect may be rationalized by interpreting delay as a form of flexibility called for by distressed borrowers to "relationship" lenders or it might simply reflect the idea that firms facing financial constraints have more to gain (at least in the short term) by defaulting against banks to whom they owe more. Another possible explanation is that firms with large loans are, paradoxically, in a stronger bargaining position vis-à-vis the bank, because they are aware of the possible reluctance of banks to formally classify large loans as "bad".

We find no evidence that bank size or bank profits affect default behavior. We also find no evidence that bank liquidity stress - either from a low share of assets in liquid investments or heavy reliance on wholesale fund (low stable funds) - affects default. This last non-result contrasts sharply with that of Ippolito et al. [2015], who show that firm drawdowns on credit lines increase at banks facing funding pressures around the Lehman bankruptcy. The 
difference in results is likely to reflect the different periods investigated by the two papers. Specifically, we do not focus on the immediate aftermath of the Lehman bankruptcy, but consider a longer period which is characterized by massive injection of liquidity by the European Central Bank that strongly alleviated liquidity shortages and funding problems of European banks.

\subsubsection{Results by firm size and bank share}

Table 6 extends the baseline model by allowing the marginal effect of bank characteristics to vary by borrower size. We accomplish this by sorting borrowers into four equal-sized bins based on total assets and allowing the slope coefficients to differ for each group (the direct effect of the firm size-bin indicators, like all other firm characteristics, gets absorbed by the firm-time effects). These results accomplish two goals. First, they show that the main result - increased delayed-payment default at banks exposed to past bad loans - is robust across the firm-size distribution in most specifications. Second, the magnitude of this effect grows with firm size, and these differences are statistically significant at conventional levels in the specification including bank profits (see F-statistics in Table 6 that tests the equality of the

bad loan coefficient across size classes). Thus, firms with greater bargaining power due to a better ability to switch lenders - large firms - seem more apt to take advantage by not paying their banks weakened by past bad loans.

Like Table 6, Table 7 extends the baseline model, this time by allowing the marginal effect of bank characteristics to vary with the firm's share of borrowing from the bank. Here, we test whether an increase in the importance of the bank to the firm - a plausible measure of the strength of the bank relationship - affects the firm's willingness to default selectively. We find no such evidence. The share of total borrowing from a given bank does not interact significantly with any measure of bank characteristic, including past bad loans. 


\subsection{Judicial efficiency and selective default}

Table 8 reports the baseline model augmented with interactions of the bank characteristics with our measure of enforcement - the natural log of the average durations for property execution proceedings (inefflaw) - which varies widely across judicial courts (recall Figure $2) .^{21}$

These results show that bank weakness affects firm-level default choices most in areas with weak enforcement (columns (5), (8) and (9)). The positive interaction between bank health (bad loans) and weak enforcement also demonstrates that the default behavior reflects borrower rather than lender decisions. One alternative explanation for the main effect in Table 5 might be that weak lenders invoke their contractual rights to force early repayment more aggressively than less-distressed lenders. This would generate greater defaults at more distressed lenders, even for the same borrower. But this behavior would be more attractive for lenders operating where their ex post bargaining power, due to efficient court proceedings, is strong. We find, instead, that the behavior happens most where borrower's bargaining power is strong (in addition, we do not use default events in which loan's terms have been restructured; these cases would reflect negotiation between borrower and lender).

To understand magnitudes, Figure 3 plots the marginal effect of bad loans on default likelihood as a function of the level of enforcement, from the 5th to the 95th percentile of its distribution. The marginal effect of bad loans clearly increases in the length of time for property execution in court. At the mean, the marginal effect of bad loans is about 0.09 $(=-1.301+0.196 \times \ln (1189)$; see column (8)), close to what we find in the non-interactive regressions of Table 7 . The effect implies that a one standard deviation increase in bad loans would increase defaults by about 0.5 percentage points. In contrast, where enforcement is poor - one standard deviation lower than average (e.g. Cosenza) - the effect roughly doubles. In courts with good enforcement (e.g. Crema), in contrast, the effect of past bad loans on

\footnotetext{
${ }^{21}$ The main effect of inefflaw is absorbed by the bank fixed effect since inefflaw is time-invariant and the jurisdiction is assigned on the basis of the legal residence of the bank.
} 
defaults is small and not statistically significant (standard error bands surround zero). This variation emphasizes the importance of legal enforcement, as we only see evidence of firms selectively defaulting against weak banks where their ex post ability to enforce is weak. Thus, where enforcement is weak borrowers pay mainly to preserve access to future credit, much as the incentive of sovereign governments to repay debt resides primarily in their concern about borrowing in future years [Shleifer, 2003].

Table 9 re-introduces the firm-size interaction effects, again by estimating slope coefficients separately across size bins. Since the model now has both a direct effect and an interactive effect, we estimate a pair of coefficients on each bank characteristic in each of the four firm-size bins (i.e., eight coefficients for each bank characteristic). These models suggest the following: 1) banks with more bad loans face a greater level of default, confirming the previous result; 2) this result is substantially stronger in regions with poor legal enforcement, again confirming Table 8; and, 3) this result is robust across borrower size categories. That said, the evidence in Table 6 - that the tendency to default selectively increases with borrower size - appears less compelling. We do find a stronger effect of bank exposure to bad loans on default for the largest vs. the second-to-largest group of firms, but the coefficient bands for the parameters of these two groups are overlapping and if we test the joint hypothesis across all four size bins, we fail to reject the null that the two pairs of coefficients are equal.

\subsection{Strategic v. Selective Default}

We have consistently used the term 'selective' default to describe our results. We do so because our identification strategy exploits only variation from firms that select to default against one or more of its lenders while continuing to pay others. One issue that this approach does not address is whether some of these selective defaults are really strategic. That is, do some borrowers pay less than they otherwise would because one or more of their lenders is distressed? Or, do borrowers (many of whom are themselves distressed) pay as much as they can, regardless of bank health, but actively select which bank to pay and which not 
to pay? Selective but not strategic behavior, while interesting, would imply that the overall amount of total default would not be affected by bank weakness. In fact, one might even argue that selective default could be helpful by weeding out weak banks faster than might otherwise occur. Quantifying the amount of strategic behavior is difficult in our setting, but one approach we can offer is to estimate our model separately by borrower credit worthiness.

Table 10 reports such tests, with a structure parallel to that of Table 9. Rather than sorting by size, here we sort by borrower risk. In particular, we separate firms into three risk bins based on the z-score, which summarizes credit quality. ${ }^{22}$ Firms with z-scores less than or equal to three are defined as safe, those with scores between four and six as vulnerable, and those with scores equal to and above seven as risky. The results suggest, first, that the effect of bank distress on default is robust across all three firm types; in each case we see that the bad loans ratio affects default most in areas with weak legal enforcement. Magnitudes increase across the three risk bins, but this make sense because the mean level of default rises with the z-score and thus leads to larger coefficients. In each bin, the marginal effect of badloans on default is close to zero in areas with high levels of judicial efficiency and then increases, becoming positive and significant, as judicial efficiency worsens. This is illustrated graphically in Figure 4, which reports the marginal effect of badloans on default for each firm type across the distribution of judicial efficiency (inefflaw). Even for the safest category of firms, we find evidence that default increases with bank distress in areas of poor legal enforcement. As shown in Figure 5, the marginal effect of badloans on default becomes positive and statistically significant for most of the distribution of legal inefficiency above its average. This suggests that truly strategic default sometimes occurs. Defaults are higher when lenders are weak (due to high bad loans) and legal enforcement is poor, even for the lowest risk borrowers. Low risk borrowers have the capacity to pay but sometimes choose not to pay, indicating the presence of strategic default and therefore less overall debt repayment

\footnotetext{
${ }^{22}$ The score variable measures the probability of a firm defaulting on the basis of an adaptation to Italy of Altman [1968]'s approach, developed by Cerved SPA and regularly used by Italian banks to assess a firm's riskiness. The Score index ranges from one for firms least likely to default to nine for firms most likely to default.
} 
due to bank weakness and poor enforcement.

\subsection{Borrowing Costs and and Legal Efficiency}

Our results help explain why credit supply has been shown to respond so strongly to the strength of legal enforcement. Not only does weak enforcement reduce ex post returns when loans default idiosyncratically, our results suggest also that losses can be contagious and lead to default probabilities that increase across a lender's entire loan portfolio. Crucially, weak enforcement exacerbates this risk of borrower contagion. Thus, weak enforcement increases a bank's systematic loan risk by raising the chance that borrowers default en masse once the likelihood of bank survival becomes sufficiently in doubt. If this risk is understood by banks ex ante, then credit supply should be adversely affected in parts of Italy where legal efficiency is poor. This may lead to higher borrowing costs and/or to less credit availability. In fact, earlier research focusing on variation across Italian provinces found that indicators of credit availability are negatively related to judicial inefficiency and, in some specifications, positively related to borrowing costs (see Jappelli et al., 2005) ${ }^{23}$.We focus here on borrowing costs and find evidence that loan interest rates are higher where legal efficiency is poor (see Table 11). More precisely, we regress the interest rate on measures of firm credit quality (equal to indicator variables based on the borrower credit score), time fixed effects, and our measure of legal inefficiency. We report the model only for observations in which the bank and the borrower reside in the same province, so there is not ambiguity regarding measurement of legal efficiency. Since we are interested in the direct correlation between

\footnotetext{
${ }^{23}$ More precisely, the average interest rate on short term loans to non financial companies in a province is positively associated cross sectionally with the stock of pending trials. In the fixed effect specification the length of civil trials is positively and almost significantly associated with the interest rate at conventional significance level, but the stock of pending trials has a negative, but insignificant effect. The stock of pending trials has a negative and significant effect on credit avauilability both cross sectionally and in the fixed effect specification. The predictions of the theoretical model in Jappelli et al. [2005] depend upon the competitive structure of banks and other details. Longer longer recovery time for posted collateral tends to lead to lower interest rates under perfect competition in ceredit markets, but not under monopolistic competition. In both cases, longer recovery times imply less credit availability. Note also that the prediction on average interest rates depends also upon the different pool of applicants in provinces/times with different collateral recovery times.
} 
legal inefficiency and loan pricing, we must leave out the bank and firm*time (or firm) fixed effects, as these would subsume the coefficient of interest. Hence, omitted variables could be problematic in the regression.

Given this caveat, we see a very strong positive and statistically significant effect of legal inefficiency on loan pricing. The effect is similar in models with and without additional firm control variables such as log of total assets, leverage and age (column 1 vs. 2). The magnitude suggests that the loan rate increases by 0.40 percentage points comparing loans to borrowers in legal jurisdictions at the 25th percentile vs. those at the 75 th (and by 80 basis points going from the 5 th to the 95 th percentile). The coefficient of interest remains significant after including macro-regional indicator variables, although the magnitude is somewhat smaller.

\subsection{Robustness Tests}

Table 12 reports six robustness tests of our main model with legal efficiency (i.e. the models of Table 8). First, we report the model using term loans only. Second, we report the model after discarding all data beyond the first quarter in which a loan becomes late (or overdrawn). Third, we control for four dimensions of loan terms. Fourth, we reduce our sample and include only observations in which the bank and the lender reside in the same court jurisdiction. Fifth, we replace bank fixed effects with bank-firm effects. And sixth, we allow for the effect of accumulated bad loans to differ not only according to the efficiency of the court, but also based on the macro region a firm resides in. ${ }^{24}$

\subsubsection{Term Loans Only}

By excluding credit lines from our dataset, we can help ensure that the behavior reflects the borrower's intent not to repay the loan. Credit line data combine variation generated both by the borrower's delays in re-payment of existing balances, and variation stemming from the borrower's demand for liquidity. Specifically, delayed re-payment on an existing credit line

\footnotetext{
${ }^{24}$ Since the results when bank profits are included are very similar, we present only the results for the larger quarterly sample without this control variable.
} 
will mechanically lead to an increase in the drawn balance, just as an active increase by the borrower in the amount drawn. As long as the drawn balance remains below the maximum amount of the line, we have no way to determine what motivates the borrower. A second problem with credit lines is that the bank's choice to cut credit limits could also make default more likely. Thus, data on credit lines may confound our interpretation. No such problems exist with respect to term loans, since the balance of the loan is fixed throughout the life of the loan. Thus, this robustness test allows us to sharpen the distinction between bank vulnerability stemming from liquidity exposure (the traditional concern) and vulnerability stemming from credit-risk exposure (our focus).

Column (1) of Table 12 reports these results. Focusing only on term loans confirms our main message: borrowers selectively default against weak banks in regions with poor enforcement. Term loans have no liquidity component, so this result can only reflect credit risk and not liquidity. The coefficient magnitudes are somewhat smaller than those observed when we model overall default, but this reflects the lower level of default of term loans vs. lines.

\subsubsection{First Delay}

The next set of regressions (column (2)) report the main results with just the first instance in which a loan becomes late on a payment (or overdrawn). This test alleviates the concern that persistence in the error term leads to a bias in estimating the effects of past bad loans on delayed repayment. The problem is twofold. First, once borrowers become late on a loan, that lateness becomes persistent; late borrowers tend to stay late for many consecutive quarters. Second, loans that are late (or overdrawn) often transition to the bad-loan account. This pattern is evident in the transition matrix described earlier (recall Table 1b). Persistence in the error term after loans become late would therefore induce a contemporaneous correlation between the error and the level of bad loans for observations after the first instance of default. To remove this source of bias, we simply drop all observations after 
a loan first enters the state of late payment. The basic pattern of the regression results remains similar, with even stronger statistical significance. The magnitudes fall, but this is as expected because by dropping all instances of late payments after the first one, we reduce the mean level of the dependent variable by more than $50 \%$.

\subsubsection{Control for Loan Terms}

As we have emphasized, our model fully absorbs all firm-level fundamentals by capturing firm-quarter fixed effects. However, loan terms - interest rates, collateral, and maturity - are not captured this way, since these may vary systematically across a firm's banking relationships. We therefore control for the loan interest rate, the share of loans with maturity less than one year, the average ratio of collateral in accounts receivable to loan size, and the average ratio of real-estate collateral to loan size. Each of these variables reflects variation at the firm-lender-quarter level, so coefficients remain identified even with the firm-quarter fixed effects. In some cases loan terms are not available, so the sample falls in these models. ${ }^{25}$

We find in column (3) that higher interest rates are associated with more default, which seems sensible given that the firm can save more cash resources by delaying payment on more expensive loans. We find that shorter maturity loans are more likely to default. And we find some evidence that collateral mitigates default risk (at least for accounts receivable; real estate collateral does not enter the model robustly). But what is most salient for us: adding these variables does little to our results of interest. In fact, we find somewhat stronger results, although this in part may reflect differences in the sample.

\subsubsection{Borrower and Lender in Same Court Jurisdiction}

Next, we include only instances in which lender and borrower are located in the same court jurisdiction. This alternative sample, which is much smaller than our main sample, accounts for possible measurement error in mapping legal enforcement into the data. As noted above,

\footnotetext{
${ }^{25}$ Specifically, data on interest rates on loans are available from the Bank of Italy's Loan Interest Rate Survey, which collects data from around 200 banks accounting for over $90 \%$ of total outstanding loans.
} 
ex post enforcement requires lenders first to receive an injunction from the court jurisdiction of its head office and, to reposess collateral (or other borrower's assets), they also need to adjudicate in the court located near the collateral. Thus, legal enforcement in both court jurisdictionss may matter. By focusing on cases in which the two overlap, we can test whether potential mis-classification could generate (or bias) our findings. ${ }^{26}$

These results (column (4) of Table 12) again support the idea that lender weakness (bad loans) raises default in areas with weak enforcement. If anything, these results are stronger than those reported in our main model, meaning that the effect of bad loans on default exhibits greater sensitivity to legal efficiency in this smaller sample.

\subsubsection{Controlling for Possible Endogeneity of Borrower-Lender Matching}

With the results of column (5), we rule out the possibility that endogenous matching between firms and banks could explain our results. For example, one concern might be that firms sometimes choose a lender located in an area with poor legal enforcement with the intention of defaulting. We do this by simply incorporating a unique fixed effect for each bank-firm pair. These effects will 'control' non-parametrically for all aspects driving the firm's choice of its lender.

The results provide little evidence that endogenous sorting affects firm default behavior. We continue to find that firms default more when their lender is distressed. At the mean level of legal enforcement, the marginal effect of bad loans on default equals $0.08(=-1.077+$ $0.163 \times \ln (1189)$ ), very close to what we observe in our model with just bank effects (as in Table 8).

\footnotetext{
${ }^{26}$ The large drop in the sample occurs because the majority of loans are extended by the largest banks with branches located across the whole of Italy. So, even though borrowers are usually located near a branch of their lender, they often are not located near the lender's head office. Thus, this sample filters out most loans extended by the largest banks and suggests robustness with respect to lender size as well as legal efficiency measures.
} 


\subsubsection{Allowing for Differences Across Macro Regions}

One may wonder whether the differences in the importance of bank health across court jurisdictions proxies for more complex differences between southern and northern regions. As we have seen, we have meaningful variation across both regions, but judicial efficiency is clearly higher (inefflaw is lower) on average in the north of Italy. Moreover, many authors have pointed to cultural differences across the two areas. These include differences in social capital, trust, and respect for others outside the family. ${ }^{27}$ Such difference could plausibly affect a firm's willingness to default selectively.

To test whether these alternative sources of variation explain our results, we incorporate additional regressors interacting the bank characteristics with an indicator set to one for the southern regions (and major islands). Our focus is on the interaction between badloans and inefflaw $\times$ badloans with this regional indicator. This specification allows the effect of badloans on default to vary regionally as well as across judicial areas. The coefficients on these additional variables capture the difference between the south (and island regions) relative to the center and north of Italy. Column (6) shows, however, that the regional interactions are not statistically significant, either individually or jointly. For example, the F-test for the significance of two additional interactions with badloans and inefflaw $\times$ badloans has a p-value of 0.442 . So, we conclude that judicial inefficiency is the main factor determining the marginal effect of accumulated bad loans on the decision to delay payments.

\section{Conclusions}

This paper provides the first empirical evidence that banks can be vulnerable to run-like behavior when borrowers choose to delay payment in response to evidence of their bank's distress from past bad loans. These results are strong, both statistically and economically, at those Italian banks which operated in areas with weak legal enforcement. Most of the finance

\footnotetext{
${ }^{27}$ See for instance, Putnam et al. [1994], Guiso et al. [2004], Guiso et al. [2013a] and Guiso et al. [2013b].
} 
and economics literature, as well as the policy and regulatory apparatus, have viewed the roots of bank vulnerability as stemming from exposure to liquidity risk. Although exposure to credit risk is a well-known source of bank losses, we find a new channel through which credit risk might impair bank stability: delay in payments motivated by bank weakness. We even demonstrate that where enforcement is weak, even the safest borrowers delay loan repayment to weak banks. Our results help explain why the law and finance literature has found weak enforcement of creditor rights to be so detrimental to well functioning debt markets [La Porta et al., 1998].

Fragility from liquidity exposure has been addressed with mechanisms like deposit insurance, liquidity requirements (called for by the Basel III reform package) and lender of last resort facilities operated by central banks. It seems likely that better enforcement, such as improving the speed and certainty with which creditors can take possession of borrower's net worth would reduce fragility stemming from credit risks and limit, in turn, the use of those lenders of last resort facilities that might carry costs by encouraging banks to increase leverage, issue too much short-term debt, and take excessive risk.

Our paper also contributes to the debate on the role of information, market discipline and bank stability: while access to timely and reliable information enables investors to assess risks inherent to financial assets and to allocate capital efficiently, full transparency might sometimes have detrimental effects if it leads to overreaction by market participants. Our results suggest that in bad times, dissemination of information on lender fragility might push borrowers to delay loan repayments against weak banks, making their condition even worse. 


\section{References}

Ugo Albertazzi and Domenico J. Marchetti. Credit Supply, Flight to Quality and Evergreening: an Analysis of Bank-Firm Relationships after Lehman. Temi di Discussione (Economic Working Papers) 756, Bank of Italy, Economic Research and International Relations Area, April 2010.

Edward I. Altman. Financial Ratios, Discriminant Analysis and the Prediction Of Corporate Bankruptcy. Journal of Finance, 23(4):589-609, September 1968.

Pierluigi Balduzzi, Emanuele Brancati, and Fabio Schiantarelli. Financial Markets, Banks' Cost of Funding, and Firms' Decisions: Lessons from Two Crises. Boston College Working Papers in Economics 824, Boston College Department of Economics, 2014.

Bank of Italy. Governor's Concluding Remarks, 2015a. URL https://www.bancaditalia. it/pubblicazioni/interventi-governatore/integov2015/en_cf_2014.pdf? language_id=1.

Bank of Italy. Relazione Annuale, Appendice, 2015b. URL https://www.bancaditalia. it/pubblicazioni/relazione-annuale/2014/appendice_2014_completa.pdf.

Marcello Bofondi, Luisa Carpinelli, and Enrico Sette. Credit Supply During a Sovereign Debt Crisis. Temi di Discussione (Economic Working Papers) 909, Bank of Italy, Economic Research and International Relations Area, April 2013.

Patrick Bolton, Xavier Freixas, Leonardo Gambacorta, and Paolo Emilio Mistrulli. Relationship and Transaction Lending in a Crisis. Temi di Discussione (Economic Working Papers) 917, Bank of Italy, Economic Research and International Relations Area, July 2013.

Emilia Bonaccorsi di Patti and Enrico Sette. Bank Balance Sheets and the Transmission of Financial Shocks to Borrowers: Evidence from the 2007-2008 Crisis. Temi di Discussione 
(Economic Working Papers) 848, Bank of Italy, Economic Research and International Relations Area, January 2012.

Philip Bond and Ashok S. Rai. Borrower Run. Journal of International Economics, 89: 185-191, 2009.

Amanda Carmignani and Silvia Giacomelli. Italian Civil Justice: Regional Disparities. Questioni di Economia e Finanza (Occasional Papers) 40, Bank of Italy, Economic Research and International Relations Area, February 2009.

Vinicius Carrasco and Pablo Salgado. Coordinated Strategic Defaults and Financial Fragility in a Costly State Verification Model. Journal of Financial Intermediation, 23:129-139, 2014.

Federico Cingano, Francesco Manaresi, and Enrico Sette. Does Credit Crunch Investments Down? New Evidence on the Real Effects of the Bank-Lending Channel. Mo.Fi.R. Working Papers 91, Money and Finance Research Group (Mo.Fi.R.) - Univ. Politecnica Marche Dept. Economic and Social Sciences, December 2013.

Marcia Millon Cornett, Jamie John McNutt, Philip E. Strahan, and Hassan Tehranian. Liquidity Risk Management and Credit Supply in the Financial Crisis. Journal of Financial Economics, 101(2):297-312, August 2011.

D. W. Diamond and P. H. Dybvig. Bank Runs, Deposit Insurance, and Liquidity. Journal of Political Economy, 91:401-419, 1983.

Simeon Djankov, Rafael La Porta, Florencio Lopez de Silanes, and Andrei Shleifer. Courts. The Quarterly Journal of Economics, 118(2):453-517, 2003.

Viktar Fedaseyeu. Debt Collection Agencies and the Supply of Consumer Credit. Working Papers 15-23, Federal Reserve Bank of Philadelphia, June 2015. 
X. Freixas, L. Laeven, and J.L. Peydro. Systemic risk, crises and macroprudential policy. MIT Press, 2015.

Douglas Gale and Martin Hellwig. Incentive-Compatible Debt Contracts: The One-Period Problem. Review of Economic Studies, 52(4):647-663, 1985.

Silvia Giacomelli and Carlo Menon. Firm Size and Judicial Efficiency: Evidence from the Neighbour's Court. Temi di Discussione (Economic Working Papers) 898, Bank of Italy, Economic Research and International Relations Area, January 2013.

Gary Gorton and Andrew Metrick. Securitized Banking and the Run on Repo. Journal of Financial Economics, 104(3):425-451, 2012.

Reint Gropp, John Karl Scholz, and Michelle J White. Personal Bankruptcy and Credit Supply and Demand. The Quarterly Journal of Economics, 112(1):217-51, February 1997.

Luigi Guiso, Paola Sapienza, and Luigi Zingales. The Role of Social Capital in Financial Development. American Economic Review, 94(3):526-556, June 2004.

Luigi Guiso, Paola Sapienza, and Luigi Zingales. The Determinants of Attitudes toward Strategic Default on Mortgages. Journal of Finance, 68(4):1473-1515, August 2013a.

Luigi Guiso, Paola Sapienza, and Luigi Zingales. Long-term Persistence. Journal of the European Economic Association (forthcoming), July $2013 \mathrm{~b}$.

Filippo Ippolito, Jose Luis Peydro, Andrea Paolo, and Enrico Sette. Double Bank Runs and Liquidity Risk Management. Bank of Italy, February 2015.

Victoria Ivashina and David Scharfstein. Bank lending during the financial crisis of 2008. Journal of Financial Economics, 97(3):319-338, 2010.

Tullio Jappelli, Marco Pagano, and Magda Bianco. Courts and Banks: Effects of Judicial Enforcement on Credit Markets. Journal of Money, Credit and Banking, 37:223-244, 2005. 
Rafael La Porta, Florencio Lopez de Silanes, Andrei Shleifer, and Robert W. Vishny. Legal Determinants of External Finance. Journal of Finance, 52(3):1131-50, July 1997.

Rafael La Porta, Florencio Lopez de Silanes, Andrei Shleifer, and Robert W. Vishny. Law and Finance. Journal of Political Economy, 106(6):1113-1155, December 1998.

Giovanni Legorano. Loans Sour for Italy's Banks. The Wall Street Journal, November 2013. URL http://www.wsj.com/articles/ SB10001424052702304243904579195930128307274.

Filippo De Marco. Bank Lending and the Sovereign Debt Crisis. Bocconi University, June 2015.

Stephen Morris and Hyun Song Shin. Rethinking Multiple Equilibria in Macroeconomic Modeling. In NBER Macroeconomics Annual 2000, Volume 15, NBER Chapters, pages 139-182. National Bureau of Economic Research, Inc, 2001.

Fabio Pavesi. Quelle 33 banche con crediti malati sopra il 20\%. Il Sole 24 Ore, February 2015. URL http://www.ilsole24ore.com/art/notizie/2015-02-14/ quei-33-istituti-crediti-malati-sopra-20percento-081320.shtml?grafici\& refresh_ce=1.

Alexander Popov and Neeltje van Horen. The Impact of Sovereign Debt Exposure on Bank Lending: Evidence from the European Debt Crisis. DNB Working Papers 382, Netherlands Central Bank, Research Department, June 2013.

Robert D. Putnam, Robert Leonardi, and Raffaella Y. Nanetti. Making Democracy Work: Civic Traditions in Modern Italy. Princeton University Press, Princeton, NJ, 1994.

Michael R. Roberts and Amir Sufi. Financial Contracting: A Survey of Empirical Research and Future Directions. Annual Review of Financial Economics, 1(1):207-226, November 2009. 
Jonathan A. Scott and Terrence Smith. The Effect of the Banktruptcy Reform Act of 1978 on Small Business Loan Prices. Journal of Financial Economics, 16:119-140, 1986.

Andrei Shleifer. Will the Sovereign Debt Market Survive? American Economic Review, 93 (2):85-90, May 2003.

Philip E. Strahan. Too Big to Fail: Causes, Consequences and Policy Responses. Annual Review of Financial Economics, 5:43-61, 2013.

R. M. Townsend. Optimal Contracts and Competitive Markets with Costly State Verification. Journal of Economic Theory, 21(2):265-293, 1979.

Stefan T. Trautmann and Razvan Vlahu. Strategic Loan Defaults and Coordination: An Experimental Analysis. Journal of Banking and Finance, 37(3):747-760, 2013.

Giada Zempano. Renzi Takes Aim at Italy's Slow Courts. Wall Street Journal, 2014. 


\section{Data appendix}

\section{Loan quality and lending relationship - Source: Credit Register, Bank of Italy}

late payment $(0,1)$ : bank, firm, quarter-level, $=1$ if the firm has a past due/overdrawn with the bank in the quarter; $=0$ if loans granted by the bank to the firm are performing in the quarter;

bkshare: bank, firm, quarter-level, firm's share of borrowing from the bank in the quarter;

past due/overdrawn: exposures (other than those classified as bad loans, substandard or restructured) whose repayments have been delayed by the borrowers for more than 90 days on a continuous basis;

substandard: exposures to counterparties which face temporary difficulties expected to be overcome within a reasonable period of time;

objective substandard: past due/overdrawn classified as "substandard";

restructured: exposures in which lenders, as a result of the deterioration of the borrower's financial situation, agree to change the original conditions, giving rise to a loss for the creditor;

bad loans: exposures to insolvent counterparties (even if not legally ascertained), regardless of any loss estimate made by the bank and irrespective of any possible collateral or guarantee;

\section{Bank characteristics - Source: Supervisory Reports, Bank of Italy}

total assets, bank, quarter-level; eur millions;

lntot:bank, quarter-level; total assets, eur millions (log of);

badloans: bank,quarter-level, bad loans/total assets, ratio;

profits: bank-level, by-annual, return on equity, ratio;

liquidity: bank, quarter-level, (cash and gov. bonds) /total assets, ratio;

capital: bank, quarter-level equity/total assets, ratio;

stable funding: bank, quarter-level, deposits from residents and bank bonds with households/total assets, ratio;

govbshock: bank, quarter-level, bank losses from sovereign bonds holdings; source: Author's estimates based on data from Supervisory Reports, Bank of Italy. See the upcoming description for details 
An index of bank losses from sovereign bonds holdings (govbshock) - Source: Author's estimates based on data from Supervisory Reports, Bank of Italy

We follow De Marco (2015) to compute the change in the value sovereign holdings (govbshock) using the change in the yield ( $\triangle$ yield $)$ for each type of bond (based on maturity and country), multiplied by the product of the bond's duration times its share of the bank's total assets (govbondshare). We limit ourselves to bonds issued by the Italian government because they represent the vast majority of holdings of sovereign bonds. Govshock is defines as

$$
\text { govbshock }_{b, t}=\sum_{m} \text { duration }_{m, t} \times \text { syield }_{m, t} \times \text { govbondshare }_{m, t-1},
$$

where $m$ denotes the original bond maturity. For a zero coupon bond the formula can be written as:

$$
\text { duration }_{m, t}=\frac{2 m}{1+\text { yield }_{m, t}}
$$

For a par bond, the formula simplifies to

$$
\text { duration }_{m, t}=\frac{1}{\text { yield }_{m, t}}\left[1-\frac{1}{\left(1+\text { yield }_{m, t}\right)^{2 m}}\right] .
$$

We apply the first formula when we know that the sovereign bonds are discount bonds and an average of the two formulae when we have no such information.

Efficiency of justices - Source: Authors' estimates from data disseminated by the Italian Ministry of Justice inefflaw: court jurisdiction-level, Length of Property executon proceedings in days (log of);

Firm characteristics - Source: Balance sheet register

employees: firm, year-level;

firm assets: firm, year-level;

debt/assets: firm, year-level;

age: firm, year-level; 


\section{Table 1: Summary Statistics}

The table shows statistics on problematic loans for a sample of around 32,000 industrial firms based in Italy. The description of variables and their data sources are given in the Data Appendix.

(a) Loan Quality in Italy (Sampled Firms)

\begin{tabular}{lrrrrrrrrr}
\hline & 2006 & 2007 & 2008 & 2009 & 2010 & 2011 & 2012 & 2013 & 2014 \\
\hline Performing & 0.986 & 0.987 & 0.982 & 0.956 & 0.936 & 0.922 & 0.909 & 0.880 & 0.853 \\
Bad Loans & 0.000 & 0.000 & 0.002 & 0.008 & 0.017 & 0.025 & 0.035 & 0.052 & 0.071 \\
Restructured & 0.002 & 0.002 & 0.002 & 0.007 & 0.014 & 0.017 & 0.018 & 0.016 & 0.019 \\
Past Due/Overdrawn & 0.009 & 0.008 & 0.010 & 0.013 & 0.012 & 0.015 & 0.011 & 0.011 & 0.008 \\
Substandard & 0.003 & 0.002 & 0.005 & 0.016 & 0.021 & 0.021 & 0.027 & 0.040 & 0.049 \\
o.w.:objective substd. & 0.001 & 0.001 & 0.001 & 0.008 & 0.011 & 0.012 & 0.016 & 0.024 & 0.029 \\
\hline Late Payments & 0.010 & 0.009 & 0.011 & 0.021 & 0.023 & 0.028 & 0.028 & 0.038 & 0.041 \\
Late payments, excl. Credit Lines & 0.008 & 0.007 & 0.010 & 0.018 & 0.018 & 0.019 & 0.023 & 0.031 & 0.034 \\
\hline
\end{tabular}

(b) Transition Matrix for the Universe of All Borrowers

\begin{tabular}{|c|c|c|c|c|c|}
\hline & & Performing & Past Due/Overdrawn & Substandard/Restructured & Bad Loans \\
\hline & & \multicolumn{4}{|c|}{ Loan State at $12 / 2010$} \\
\hline \multirow{5}{*}{$\begin{array}{l}\text { Loan State } \\
\text { at } 12 / 2009\end{array}$} & Performing & $94.62 \%$ & $1.11 \%$ & $3.04 \%$ & $1.22 \%$ \\
\hline & Past Due/Overdrawn & $50.74 \%$ & $10.45 \%$ & $27.56 \%$ & $11.25 \%$ \\
\hline & Substandard/Restructured & $10.84 \%$ & $0.63 \%$ & $66.15 \%$ & $22.38 \%$ \\
\hline & Bad Loans & $0.23 \%$ & $0.02 \%$ & $0.66 \%$ & $99.09 \%$ \\
\hline & & \multicolumn{4}{|c|}{ Loan State at $12 / 2011$} \\
\hline \multirow{5}{*}{$\begin{array}{l}\text { Loan State } \\
\text { at } 12 / 2010\end{array}$} & Performing & $94.85 \%$ & $0.97 \%$ & $3.15 \%$ & $1.02 \%$ \\
\hline & Past Due/Overdrawn & $52.52 \%$ & $13.12 \%$ & $25.35 \%$ & $9.01 \%$ \\
\hline & Substandard/Restructured & $8.55 \%$ & $0.40 \%$ & $68.68 \%$ & $22.37 \%$ \\
\hline & Bad Loans & $0.29 \%$ & $0.02 \%$ & $0.34 \%$ & $99.35 \%$ \\
\hline & & \multicolumn{4}{|c|}{ Loan State at $12 / 2012$} \\
\hline \multirow{5}{*}{$\begin{array}{l}\text { Loan State } \\
\text { at } 12 / 2011\end{array}$} & Performing & $92.71 \%$ & $1.54 \%$ & $4.34 \%$ & $1.41 \%$ \\
\hline & Past Due/Overdrawn & $35.28 \%$ & $12.08 \%$ & $39.64 \%$ & $13.00 \%$ \\
\hline & Substandard/Restructured & $6.17 \%$ & $0.44 \%$ & $70.30 \%$ & $23.09 \%$ \\
\hline & Bad Loans & $0.11 \%$ & $0.01 \%$ & $0.38 \%$ & $99.50 \%$ \\
\hline & & \multicolumn{4}{|c|}{ Loan State at $12 / 2013$} \\
\hline \multirow{5}{*}{$\begin{array}{l}\text { Loan State } \\
\text { at } 12 / 2012\end{array}$} & Performing & $91.77 \%$ & $1.20 \%$ & $5.60 \%$ & $1.42 \%$ \\
\hline & Past Due/Overdrawn & $33.53 \%$ & $13.01 \%$ & $42.19 \%$ & $11.27 \%$ \\
\hline & Substandard/Restructured & $4.17 \%$ & $0.34 \%$ & $64.69 \%$ & $30.80 \%$ \\
\hline & Bad Loans & $0.10 \%$ & $0.01 \%$ & $0.29 \%$ & $99.60 \%$ \\
\hline & & \multicolumn{4}{|c|}{ Loan State at time $12 / 2014$} \\
\hline \multirow{4}{*}{$\begin{array}{l}\text { Loan State } \\
\text { at } 12 / 2013\end{array}$} & Performing & $92.39 \%$ & $1.04 \%$ & $5.67 \%$ & $0.90 \%$ \\
\hline & Past Due/Overdrawn & $27.49 \%$ & $13.70 \%$ & $46.91 \%$ & $11.90 \%$ \\
\hline & Substandard/Restructured & $3.97 \%$ & $0.22 \%$ & $71.86 \%$ & $23.94 \%$ \\
\hline & Bad Loans & $0.10 \%$ & $0.01 \%$ & $0.27 \%$ & $99.62 \%$ \\
\hline
\end{tabular}


Table 2: Bank Characteristics

The table shows statistics on bank characteristics used in our analysis. The main sample covers the period $2008 \mathrm{q} 4-2013 \mathrm{q} 4$.

The description of variables and their sources are given in the Data Appendix.

\begin{tabular}{lccccccc}
\hline & mean & $\mathrm{sd}$ & $\mathrm{p} 5$ & $\mathrm{p} 25$ & $\mathrm{p} 50$ & $\mathrm{p} 75$ & $\mathrm{p} 95$ \\
\hline & & & & & & & \\
total assets & 36,330 & 125,683 & 37 & 139 & 430 & 2,638 & 223,545 \\
badloans & 0.029 & 0.041 & 0.000 & 0.010 & 0.040 & 0.055 & 0.112 \\
profits & 0.021 & 0.033 & -0.042 & 0.007 & 0.022 & 0.040 & 0.074 \\
liquidity & 0.163 & 0.147 & 0.040 & 0.060 & 0.128 & 0.254 & 0.460 \\
govbshock & -0.082 & 0.551 & -0.882 & -0.196 & 0.000 & 0.035 & 0.591 \\
capital & 0.141 & 0.110 & 0.041 & 0.084 & 0.126 & 0.174 & 0.273 \\
stable funding & 0.598 & 0.307 & 0.020 & 0.414 & 0.678 & 0.859 & 0.923 \\
& & & & & & & \\
\hline
\end{tabular}

Table 3: Firm Characteristics

The table shows statistics on firm characteristics employed in our analysis. The sample covers the period $2008 \mathrm{q} 4$ - $2013 \mathrm{q} 4$. The description of variables and their sources are given in the Data Appendix.

\begin{tabular}{lcccccc}
\hline & mean & $\mathrm{p} 5$ & $\mathrm{p} 25$ & $\mathrm{p} 50$ & $\mathrm{p} 75$ & $\mathrm{p} 95$ \\
\hline & & & & & & \\
employees & 151 & 5 & 24 & 49 & 105 & 450 \\
assets & 61,214 & 3,079 & 7,814 & 14,615 & 32,370 & 149,593 \\
debt/assets & 0.294 & 0.017 & 0.128 & 0.299 & 0.443 & 0.615 \\
age & 25 & 4 & 13 & 23 & 33 & 55 \\
riskyness (Z-SCORE, 1-9) & 5 & 1 & 3 & 5 & 6 & 8 \\
& & & & & & \\
\hline
\end{tabular}

Table 4: Judicial Efficiency in Italy: Length of Property Execution Proceedings

The table presents descriptive statistics on duration of property execution proceedings in 2007 (days, court-level data).

\begin{tabular}{lccccccc}
\hline & mean & $\mathrm{sd}$ & $\mathrm{p} 5$ & $\mathrm{p} 25$ & $\mathrm{p} 50$ & $\mathrm{p} 75$ & $\mathrm{p} 95$ \\
\hline \# of days & 1,189 & 745 & 415 & 628 & 1,007 & 1,482 & 2,638 \\
& & & & & & & \\
\hline
\end{tabular}




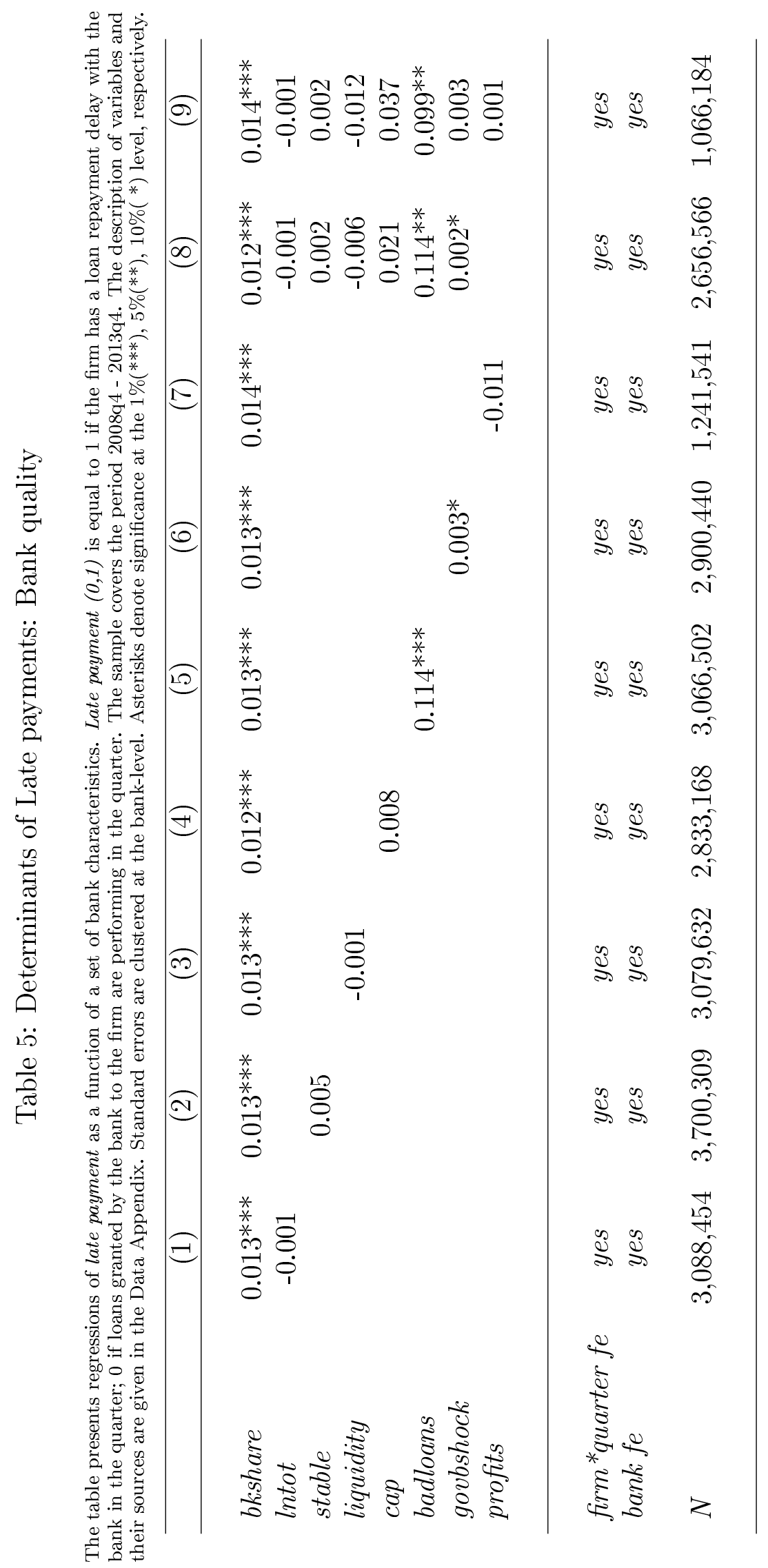


Table 6: Late payments, bank quality and firm size

The table presents regressions of late payment as a function of a set of bank characteristics. The model allows the effect of bank variables to vary by borrower size. Borrowers are sorted in four equal-sized bins based on their total assets $(1=$ small; $4=$ large $)$. Late payment $(0,1)$ is equal to 1 if the firm has a loan repayment delay with the bank in the quarter; 0 if loans granted by the bank to the firm are performing in the quarter. The sample covers the period 2008q4 - 2013q4. The description of variables and their sources are given in the Data Appendix. Standard errors are clustered at the bank-level. Asterisks denote significance at the $1 \%(* * *), 5 \%(* *), 10 \%(*)$ level, respectively.

\begin{tabular}{|c|c|c|c|c|c|}
\hline & (1) & $(2)$ & (3) & $(4)$ & $(5)$ \\
\hline bkshare & $0.013^{* * *}$ & $0.012^{* * *}$ & $0.014^{* * *}$ & & \\
\hline $\begin{array}{l}\text { bkshare_1 } \\
\text { bkshare_2 } \\
\text { bkshare_3 } \\
\text { bkshare_4 }\end{array}$ & & & & $\begin{array}{l}0.007^{* * *} \\
0.008^{* * *} \\
0.013^{* * *} \\
0.022^{* * *}\end{array}$ & $\begin{array}{l}0.008 * * * \\
0.009^{* * *} \\
0.013^{* * *} \\
0.025 * * *\end{array}$ \\
\hline $\begin{array}{l}\text { badloans_ } 1 \\
\text { badloans_2 } \\
\text { badloans_- } \\
\text { badloans_4 }\end{array}$ & $\begin{array}{c}0.052 \\
0.085^{* *} \\
0.109^{* * *} \\
0.169^{* * *}\end{array}$ & $\begin{array}{c}0.078^{* *} \\
0.084^{*} \\
0.129^{* * *} \\
0.141^{* *}\end{array}$ & $\begin{array}{c}0.077^{* *} \\
0.042 \\
0.108^{* * *} \\
0.138^{* *}\end{array}$ & $\begin{array}{c}0.077^{* *} \\
0.084^{*} \\
0.129^{* * *} \\
0.141^{* *}\end{array}$ & $\begin{array}{c}0.076^{*} \\
0.041 \\
0.108^{* * *} \\
0.138^{*}\end{array}$ \\
\hline $\begin{array}{l}\text { stable } 1 \\
\text { stable- } 2 \\
\text { stable- } 3 \\
\text { stable-4 }\end{array}$ & & $\begin{array}{l}0.001 \\
0.003 \\
0.002 \\
0.002\end{array}$ & $\begin{array}{l}0.003 \\
0.005 \\
0.000 \\
0.002\end{array}$ & $\begin{array}{l}0.001 \\
0.003 \\
0.002 \\
0.002\end{array}$ & $\begin{array}{l}0.003 \\
0.005 \\
0.000 \\
0.002\end{array}$ \\
\hline $\begin{array}{l}\text { govbshock_1 } \\
\text { govbshock-2 } \\
\text { govbshock_3 } \\
\text { govbshock_4 }\end{array}$ & & $\begin{array}{c}0.002 \\
0.002 \\
0.003^{*} \\
0.002\end{array}$ & $\begin{array}{l}0.002 \\
0.004 \\
0.003 \\
0.004\end{array}$ & $\begin{array}{c}0.001 \\
0.002 \\
0.003^{*} \\
0.002\end{array}$ & $\begin{array}{l}0.002 \\
0.004 \\
0.003 \\
0.004\end{array}$ \\
\hline $\begin{array}{l}\text { lntot_1 } \\
\text { lntot_2 } \\
\text { lntot_3 } \\
\text { lntot_4 }\end{array}$ & & $\begin{array}{c}-0.001 \\
-0.001 \\
0.000 \\
0.000\end{array}$ & $\begin{array}{c}-0.002 \\
-0.002 \\
-0.001 \\
0.000\end{array}$ & $\begin{array}{c}-0.001 \\
-0.001 \\
0.000 \\
0.000\end{array}$ & $\begin{array}{l}-0.002 \\
-0.002 \\
-0.001 \\
-0.001\end{array}$ \\
\hline $\begin{array}{l}c a p_{-} 1 \\
c a p_{2} 2 \\
c a p_{-} 3 \\
c a p_{-4}\end{array}$ & & $\begin{array}{c}0.009 \\
0.015 \\
0.03 \\
0.028\end{array}$ & $\begin{array}{l}0.033 \\
0.016 \\
0.037 \\
0.057\end{array}$ & $\begin{array}{l}0.01 \\
0.016 \\
0.029 \\
0.028\end{array}$ & $\begin{array}{l}0.034 \\
0.017 \\
0.037 \\
0.056\end{array}$ \\
\hline $\begin{array}{l}\text { liquidity_1 } \\
\text { liquidity_2 } \\
\text { liquidity_3 } \\
\text { liquidity_4 }\end{array}$ & & $\begin{array}{r}-0.014 \\
-0.015 \\
-0.007 \\
0.004\end{array}$ & $\begin{array}{c}-0.012 \\
-0.022^{* *} \\
-0.007 \\
-0.011\end{array}$ & $\begin{array}{c}-0.015 * \\
-0.015 \\
-0.007 \\
0.005\end{array}$ & $\begin{array}{c}-0.012 \\
-0.022^{* *} \\
-0.007 \\
-0.01\end{array}$ \\
\hline $\begin{array}{l}\text { prof_1 } \\
\text { prof_2 } \\
\text { prof_3 }_{3} \\
\text { prof_4 }_{4}\end{array}$ & & & $\begin{array}{c}-0.002 \\
0.01 \\
-0.006 \\
0.002\end{array}$ & & $\begin{array}{c}-0.003 \\
0.009 \\
-0.006 \\
0.002\end{array}$ \\
\hline $\begin{array}{l}\text { firm* quarter fe } \\
\text { bank fe }\end{array}$ & $\begin{array}{l}\text { yes } \\
\text { yes }\end{array}$ & $\begin{array}{l}\text { yes } \\
\text { yes }\end{array}$ & $\begin{array}{l}\text { yes } \\
\text { yes }\end{array}$ & $\begin{array}{l}\text { yes } \\
\text { yes }\end{array}$ & $\begin{array}{l}\text { yes } \\
\text { yes }\end{array}$ \\
\hline$N$ & $3,066,066$ & $2,656,258$ & $1,065,889$ & $2,656,258$ & $1,065,889$ \\
\hline
\end{tabular}

Test of equality of 'badloans' coefficient across size classes

$\begin{array}{lllll}\text { F-test (p-value) } & 0.07 & 0.02 & 0.07 & 0.02\end{array}$ 


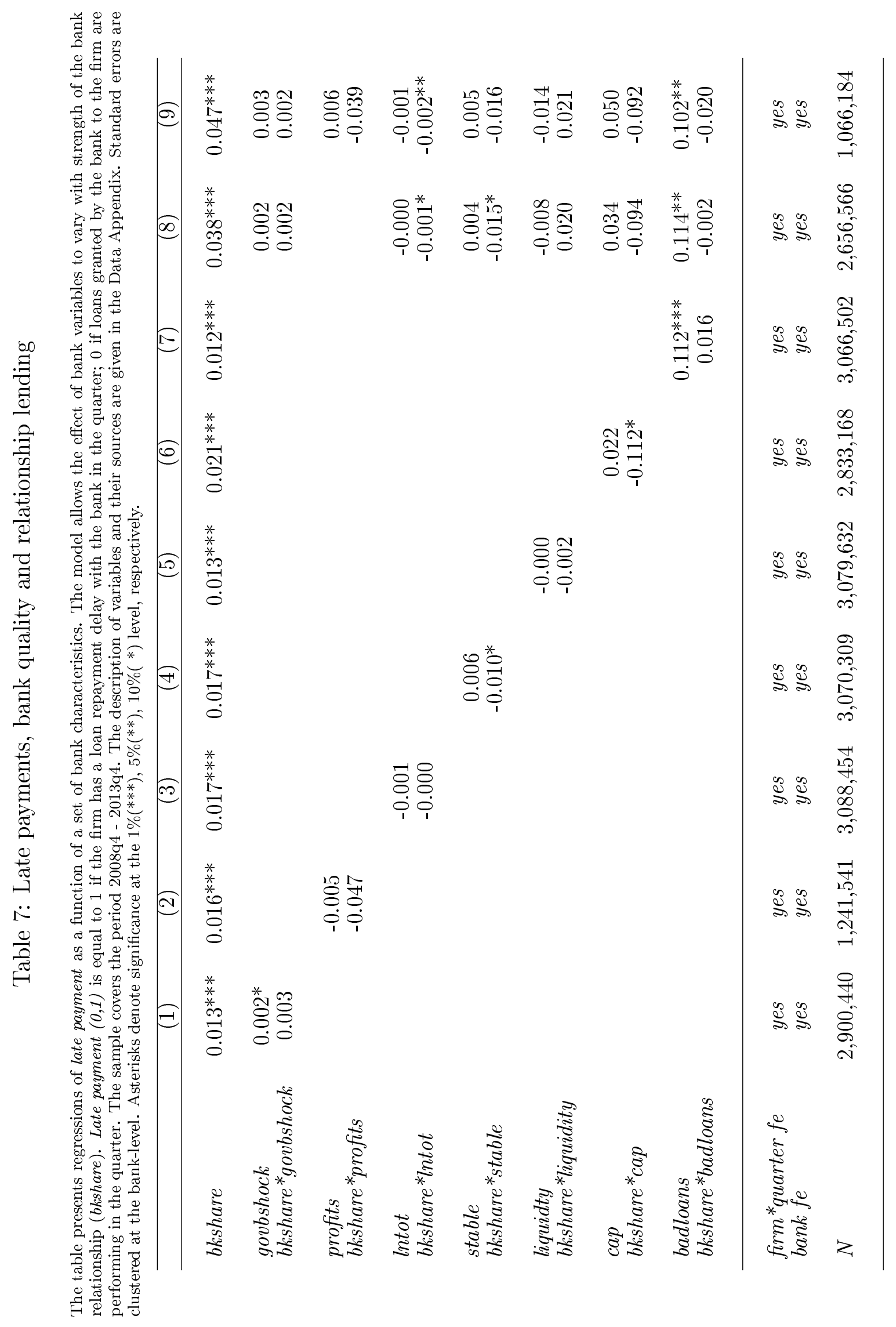




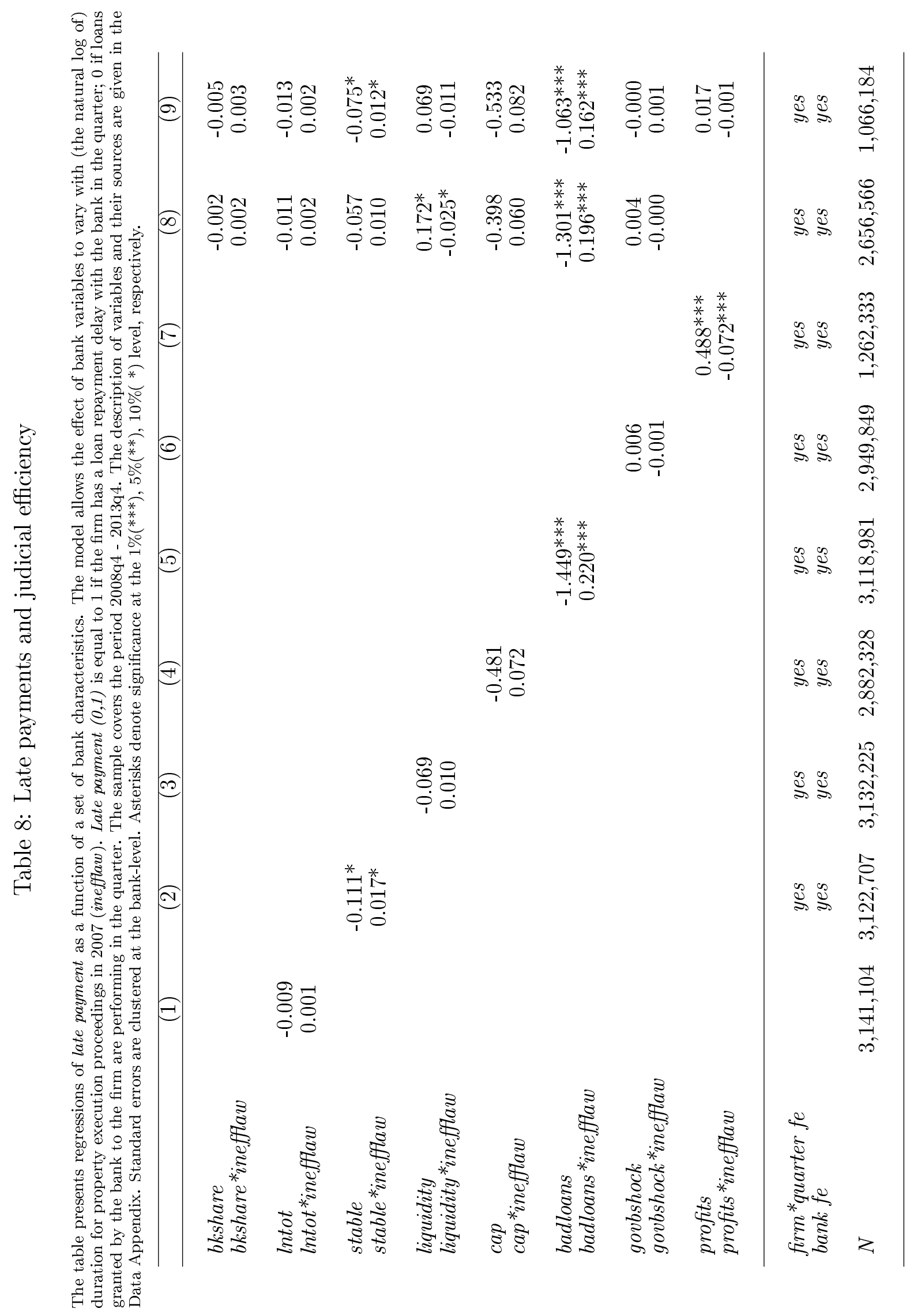




\section{Table 9: Late payments, bank quality and judicial efficiency, by firm size}

The table presents regressions of late payment as a function of a set of bank characteristics. The model allows the effect of bank variables to vary with (the natural log of) duration for property execution proceedings (inefflaw) and by borrower size. Borrowers are sorted in four equal sized-bins based on their total assets ( $1=$ smaller; $4=$ larger). The Late payment $(0,1)$ is equal to 1 if the firm has a loan repayment delay with the bank in the quarter; 0 if loans granted by the bank to the firm are performing in the quarter. The sample covers the period 2008q4-2013q4. The description of variables and their sources are given in the Data Appendix. Standard errors are clustered at the bank-level. Asterisks denote significance at the $1 \%(* * *)$, $5 \%(* *), 10 \%(*)$ level, respectively.

\begin{tabular}{|c|c|c|c|c|}
\hline & $(1)$ & $(2)$ & (3) & (4) \\
\hline $\begin{array}{l}\text { bkshare } \\
\text { inefflaw }{ }^{*} \text { bkshare }\end{array}$ & $0.012^{* * *}$ & $\begin{array}{l}0.000 \\
0.002\end{array}$ & & \\
\hline $\begin{array}{l}\text { bkshare_1 } \\
\text { bkshare_2 } \\
\text { bkshare_3 } \\
\text { bkshare_4 }\end{array}$ & & & $\begin{array}{l}0.006^{* * *} \\
0.008^{* * *} \\
0.013^{* * *} \\
0.022^{* * *}\end{array}$ & $\begin{array}{c}0.003 \\
0.003 \\
0.022 \\
-0.017\end{array}$ \\
\hline $\begin{array}{l}\text { inefflaw*bkshare_1 } \\
\text { inefflaw }{ }^{*} \text { bkshare_2 } \\
\text { inefflaw }{ }^{*} \text { bkshare_-3 } \\
\text { inefflaw }{ }^{*} \text { bkshare_4 }\end{array}$ & & & & $\begin{array}{c}0.000 \\
0.001 \\
-0.001 \\
0.006\end{array}$ \\
\hline $\begin{array}{l}\text { stable } 1 \\
\text { stable } 2 \\
\text { stable } 3 \\
\text { stable_4 }\end{array}$ & $\begin{array}{c}-0.064 \\
-0.104^{* *} \\
-0.053 \\
-0.025\end{array}$ & $\begin{array}{l}-0.064 \\
-0.104^{* *} \\
-0.053 \\
-0.025\end{array}$ & $\begin{array}{c}-0.064 \\
-0.104 * * \\
-0.053 \\
-0.024\end{array}$ & $\begin{array}{l}-0.064 \\
-0.104^{* *} \\
-0.053 \\
-0.024\end{array}$ \\
\hline $\begin{array}{l}\text { inefflaw }{ }^{*} \text { stable }{ }^{\sim} \\
\text { inefflaw }{ }^{*} \text { stable }{ }_{2} \\
\text { inefflaw }{ }^{*} \text { stable }{ }_{3} \\
\text { inefflaw }{ }^{*} \text { stable }{ }_{4}\end{array}$ & $\begin{array}{c}0.011 \\
0.017^{* * *} \\
0.009 \\
0.005\end{array}$ & $\begin{array}{l}0.011 \\
0.017^{* * *} \\
0.009 \\
0.005\end{array}$ & $\begin{array}{l}0.011 \\
0.017^{* * *} \\
0.009 \\
0.005\end{array}$ & $\begin{array}{c}0.011 \\
0.017^{* * *} \\
0.009 \\
0.005\end{array}$ \\
\hline $\begin{array}{l}\text { govb_1 } \\
\text { govb-2 } \\
\text { govb-3 } \\
\text { govb-4 }\end{array}$ & $\begin{array}{c}0.031^{*} \\
-0.021 \\
-0.010 \\
0.019\end{array}$ & $\begin{array}{c}0.031^{*} \\
-0.021 \\
-0.010 \\
0.019\end{array}$ & $\begin{array}{c}0.031^{*} \\
-0.021 \\
-0.010 \\
0.019\end{array}$ & $\begin{array}{c}0.031^{*} \\
-0.021 \\
-0.010 \\
0.019\end{array}$ \\
\hline $\begin{array}{l}\text { inefflaw* }{ }^{*} \text { govbshock_1 } \\
\text { inefflaw }{ }^{*} \text { govbshock_2 } \\
\text { inefflaw }{ }^{*} \text { govbshock_ } \\
\text { inefflaw }{ }^{*} \text { govbshock_4 }\end{array}$ & $\begin{array}{c}-0.004 \\
0.003 \\
0.002 \\
-0.003\end{array}$ & $\begin{array}{c}-0.004 \\
0.003 \\
0.002 \\
-0.003\end{array}$ & $\begin{array}{c}-0.004 \\
0.003 \\
0.002 \\
-0.003\end{array}$ & $\begin{array}{c}-0.004 \\
0.003 \\
0.002 \\
-0.003\end{array}$ \\
\hline $\begin{array}{l}\operatorname{lntot}{ }^{1} \\
\text { lntot } \\
\text { lntot } \\
\text { lntot } \\
\text { lnt }\end{array}$ & $\begin{array}{l}-0.013 \\
-0.01- \\
-0.014 \\
-0.010\end{array}$ & $\begin{array}{l}-0.013 \\
-0.010 \\
-0.014 \\
-0.009\end{array}$ & $\begin{array}{l}-0.013 \\
-0.010 \\
-0.014 \\
-0.009\end{array}$ & $\begin{array}{l}-0.013 \\
-0.010 \\
-0.014 \\
-0.009\end{array}$ \\
\hline $\begin{array}{l}\text { inefflaw* }{ }^{*} \ln t o t-1 \\
\text { inefflaw }{ }^{*} \ln t o t^{-} \\
\text {inefflaw }{ }^{*} \ln t o t^{-} \\
\text {inefflaw* }{ }^{*} t^{-} t_{4}\end{array}$ & $\begin{array}{l}0.002 \\
0.001 \\
0.002 \\
0.001\end{array}$ & $\begin{array}{l}0.002 \\
0.001 \\
0.002 \\
0.001\end{array}$ & $\begin{array}{l}0.002 \\
0.001 \\
0.002 \\
0.001\end{array}$ & $\begin{array}{l}0.002 \\
0.001 \\
0.002 \\
0.001\end{array}$ \\
\hline $\begin{array}{l}c a p_{1} 1 \\
c a p_{2} \\
c a p_{3} \\
c a p_{-4}\end{array}$ & $\begin{array}{l}-0.469 \\
-0.365 \\
-0.034 \\
-0.714\end{array}$ & $\begin{array}{l}-0.467 \\
-0.364 \\
-0.033 \\
-0.715\end{array}$ & $\begin{array}{l}-0.454 \\
-0.353 \\
-0.035 \\
-0.731\end{array}$ & $\begin{array}{l}-0.454 \\
-0.351 \\
-0.038 \\
-0.728\end{array}$ \\
\hline 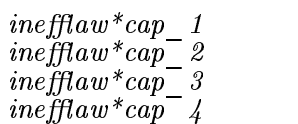 & $\begin{array}{l}0.069 \\
0.054 \\
0.008 \\
0.107\end{array}$ & $\begin{array}{l}0.069 \\
0.054 \\
0.008 \\
0.107\end{array}$ & $\begin{array}{l}0.067 \\
0.052 \\
0.008 \\
0.109\end{array}$ & $\begin{array}{l}0.067 \\
0.052 \\
0.008 \\
0.109\end{array}$ \\
\hline $\begin{array}{l}\text { badloans_1 } \\
\text { badloans_2 } \\
\text { badloans_3 } \\
\text { badloans_4 }\end{array}$ & $\begin{array}{l}-1.302^{* * *} \\
-1.584^{* * *} \\
-0.795^{* * *} \\
-1.496^{* * *}\end{array}$ & $\begin{array}{l}-1.299^{* * *} \\
-1.581^{* * *} \\
-0.793^{* * *} \\
-1.494^{* * *}\end{array}$ & $\begin{array}{l}-1.322^{* * *} \\
-1.598^{* * *} \\
-0.793^{* * *} \\
-1.485^{* * *}\end{array}$ & $\begin{array}{l}-1.321 * * * \\
-1.597 * * * \\
-0.794 * * * \\
-1.483 * * *\end{array}$ \\
\hline $\begin{array}{l}\text { inefflaw }{ }^{*} \text { badloans_ } 1 \\
\text { inefflaw }{ }^{*} \text { badloans }{ }_{2} \\
\text { inefflaw }{ }^{*} \text { badloans } 3 \\
\text { inefflaw }{ }^{*} \text { badloans }{ }_{4}\end{array}$ & $\begin{array}{l}0.193^{* * *} \\
0.233^{* * *} \\
0.127^{* * *} \\
0.225^{* * *}\end{array}$ & $\begin{array}{l}0.193 * * * \\
0.233 * * * \\
0.127 * * * \\
0.225 * * *\end{array}$ & $\begin{array}{l}0.196^{* * *} \\
0.235^{* * *} \\
0.127^{* * *} \\
0.224 * *\end{array}$ & $\begin{array}{l}0.196 * * * \\
0.235^{* * *} \\
0.127^{* * *} \\
0.224^{* * *}\end{array}$ \\
\hline $\begin{array}{l}\text { liquidity_1 } \\
\text { liquidity_2 } \\
\text { liquidity_-3 } \\
\text { liquidity_4 }\end{array}$ & $\begin{array}{c}0.206 * * \\
0.265^{* *} \\
0.082 \\
0.116\end{array}$ & $\begin{array}{c}0.204^{* *} \\
0.264^{* *} \\
0.081 \\
0.116\end{array}$ & $\begin{array}{c}0.207 * * \\
0.263 * * \\
0.082 \\
0.117\end{array}$ & $\begin{array}{c}0.207 * * \\
0.263 * * \\
0.082 \\
0.115\end{array}$ \\
\hline 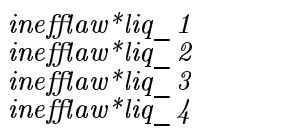 & $\begin{array}{c}-0.032 * * \\
-0.040 * * \\
-0.012 \\
-0.015\end{array}$ & $\begin{array}{c}-0.031^{* *} \\
-0.040^{* *} \\
-0.012 \\
-0.015\end{array}$ & $\begin{array}{c}-0.032^{* *} \\
-0.040^{* *} \\
-0.012 \\
-0.015\end{array}$ & $\begin{array}{c}-0.032^{* *} \\
-0.040^{* *} \\
-0.013 \\
-0.015\end{array}$ \\
\hline $\begin{array}{l}\text { firm* quarter fe } \\
\text { bank fe } \\
N\end{array}$ & $\begin{array}{c}\text { yes } \\
\text { yes } \\
2,656,258\end{array}$ & $\begin{array}{c}\text { yes } \\
\text { yes } \\
2,656,258\end{array}$ & $\begin{array}{c}\text { yes } \\
\text { yes } \\
2,656,258\end{array}$ & $\begin{array}{c}\text { yes } \\
\text { yes } \\
2,656,258 \\
\end{array}$ \\
\hline
\end{tabular}




\section{Table 10: Late payments, bank quality and judicial efficiency, by firm riskiness}

The table presents regressions of late payment as a function of a set of bank characteristics. The model allows the effect of bank variables to vary with (the natural $\log$ of) duration for property execution proceedings (inefflaw) and by borrower riskiness. Borrowers are sorted in risk bins (safe, vulnerable, risky) based on their z-score. The Late payment $(0,1)$ is equal to 1 if the firm has a loan repayment delay with the bank in the quarter; 0 if loans granted by the bank to the firm are performing in the quarter. The sample covers the period 2008q4 - 2013q4. The description of variables and their sources are given in the Data Appendix. Standard errors are clustered at the bank-level. Asterisks denote significance at the $1 \%(* * *), 5 \%(* *), 10 \%(*))$ level, respectively.

\begin{tabular}{|c|c|c|c|c|}
\hline & (1) & $(2)$ & $(3)$ & $(4)$ \\
\hline bkshare & $0.013^{* * *}$ & -0.002 & & \\
\hline $\begin{array}{l}\text { bkshare_safe } \\
\text { bkshare_vulnerable } \\
\text { bkshare_risky }\end{array}$ & & & $\begin{array}{c}-0.002 \\
0.003 \\
0.018\end{array}$ & $\begin{array}{c}-0.009 \\
0.004 \\
0.015\end{array}$ \\
\hline bkshare*inefflaw & & 0.002 & & \\
\hline $\begin{array}{l}\text { inefflaw*bkshare_safe } \\
\text { inefflaw*bkshare_vulnerable } \\
\text { inefflaw*bkshare_risky }\end{array}$ & & & $\begin{array}{l}0.001 \\
0.001 \\
0.002\end{array}$ & $\begin{array}{l}0.002 \\
0.001 \\
0.003\end{array}$ \\
\hline $\begin{array}{l}\text { stable_safe } \\
\text { stable_vulnerable } \\
\text { stable_risky }\end{array}$ & $\begin{array}{l}-0.048 \\
-0.072^{*} \\
-0.013\end{array}$ & $\begin{array}{l}-0.048 \\
-0.073^{*} \\
-0.013\end{array}$ & $\begin{array}{l}-0.046 \\
-0.072^{*} \\
-0.013\end{array}$ & $\begin{array}{l}-0.086^{*} \\
-0.087^{*} \\
-0.031\end{array}$ \\
\hline $\begin{array}{l}\text { inefflaw* }{ }^{*} \text { stable_safe } \\
\text { inefflaw }{ }^{*} \text { stable_vulnerable } \\
\text { inefflaw* }{ }^{*} \text { stable_risky }\end{array}$ & $\begin{array}{c}0.008 \\
0.012^{*} \\
0.003\end{array}$ & $\begin{array}{c}0.008 \\
0.012^{*} \\
0.003\end{array}$ & $\begin{array}{c}0.008 \\
0.012^{*} \\
0.003\end{array}$ & $\begin{array}{c}0.014^{* *} \\
0.014^{* *} \\
0.005\end{array}$ \\
\hline $\begin{array}{l}\text { gov_safe } \\
\text { gov_vulnerable } \\
\text { gov_risky }\end{array}$ & $\begin{array}{c}0.016 \\
0.013 \\
-0.026\end{array}$ & $\begin{array}{c}0.016 \\
0.013 \\
-0.025\end{array}$ & $\begin{array}{r}0.015 \\
0.013 \\
-0.025\end{array}$ & $\begin{array}{c}0.003 \\
0.01 \\
-0.015\end{array}$ \\
\hline $\begin{array}{l}\text { inefflaw*gov_safe } \\
\text { inefflaw*gov_vulnerable } \\
\text { inefflaw*gov_risky }\end{array}$ & $\begin{array}{c}-0.002 \\
-0.002 \\
0.004\end{array}$ & $\begin{array}{c}-0.002 \\
-0.002 \\
0.004\end{array}$ & $\begin{array}{c}-0.002 \\
-0.002 \\
0.004\end{array}$ & $\begin{array}{c}-0.001 \\
-0.001 \\
0.003\end{array}$ \\
\hline $\begin{array}{l}\text { lntot_safe } \\
\text { lntot_-vulnerable } \\
\text { lntot_risky }\end{array}$ & $\begin{array}{c}-0.013 \\
-0.01 \\
-0.005\end{array}$ & $\begin{array}{c}-0.013 \\
-0.01 \\
-0.005\end{array}$ & $\begin{array}{l}-0.013 \\
-0.011 \\
-0.006\end{array}$ & $\begin{array}{l}-0.016 \\
-0.012 \\
-0.009\end{array}$ \\
\hline $\begin{array}{l}\text { inefflaw }{ }^{*} \text { lntot_safe } \\
\text { inefflaw }{ }^{*} \text { lntot_vulnerable } \\
\text { inefflaw }{ }^{*} \text { lntot_risky }\end{array}$ & $\begin{array}{l}0.002 \\
0.001 \\
0.001\end{array}$ & $\begin{array}{l}0.002 \\
0.001 \\
0.001\end{array}$ & $\begin{array}{l}0.002 \\
0.001 \\
0.001\end{array}$ & $\begin{array}{l}0.002 \\
0.002 \\
0.001\end{array}$ \\
\hline $\begin{array}{l}\text { cap_safe } \\
\text { cap_vulnerable } \\
\text { cap_risky }\end{array}$ & $\begin{array}{c}-0.32 \\
-0.224 \\
-0.934^{*}\end{array}$ & $\begin{array}{l}-0.314 \\
-0.223 \\
-0.936^{*}\end{array}$ & $\begin{array}{l}-0.301 \\
-0.218 \\
-0.969^{*}\end{array}$ & $\begin{array}{l}-0.091 \\
-0.418 \\
-1.134^{*}\end{array}$ \\
\hline $\begin{array}{l}\text { inefflaw* }{ }^{*} \text { cap_safe } \\
\text { inefflaw }{ }^{*} \text { cap_vulnerable } \\
\text { inefflaw }{ }^{*} \text { cap_risky }\end{array}$ & $\begin{array}{c}0.042 \\
0.03 \\
0.154^{* *}\end{array}$ & $\begin{array}{c}0.042 \\
0.03 \\
0.154^{* *}\end{array}$ & $\begin{array}{c}0.04 \\
0.03 \\
0.159^{* *}\end{array}$ & $\begin{array}{c}0.013 \\
0.063 \\
0.183^{* *}\end{array}$ \\
\hline $\begin{array}{l}\text { badloans_safe } \\
\text { badloans_vulnerable } \\
\text { badloans_risky }\end{array}$ & $\begin{array}{l}-0.826^{* * *} \\
-1.178^{* * *} \\
-2.132^{* * *}\end{array}$ & $\begin{array}{l}-0.823^{* * *} \\
-1.176^{* * *} \\
-2.130^{* * *}\end{array}$ & $\begin{array}{l}-0.855^{* * *} \\
-1.172 * * * \\
-2.112 * * *\end{array}$ & $\begin{array}{l}-0.667^{* * *} \\
-1.056^{* * *} \\
-1.484^{* * *}\end{array}$ \\
\hline $\begin{array}{l}\text { inefflaw*bad_safe } \\
\text { inefflaw*bad_vulnerable } \\
\text { inefflaw*bad_risky }\end{array}$ & $\begin{array}{l}0.119^{* * *} \\
0.175^{* * *} \\
0.331^{* * *}\end{array}$ & $\begin{array}{l}0.118^{* * *} \\
0.175^{* * *} \\
0.331^{* * *}\end{array}$ & $\begin{array}{l}0.123^{* * *} \\
0.175^{* * *} \\
0.329^{* * *}\end{array}$ & $\begin{array}{l}0.098^{* * *} \\
0.158^{* * *} \\
0.239^{* * *}\end{array}$ \\
\hline $\begin{array}{l}\text { liquidity_safe } \\
\text { liquidity_vulnerable } \\
\text { liquidity_risky }\end{array}$ & $\begin{array}{c}0.072 \\
0.182^{*} \\
0.215\end{array}$ & $\begin{array}{c}0.069 \\
0.181^{*} \\
0.215\end{array}$ & $\begin{array}{c}0.069 \\
0.180^{*} \\
0.223\end{array}$ & $\begin{array}{c}-0.013 \\
0.1 \\
0.084\end{array}$ \\
\hline $\begin{array}{l}\text { inefflaw*liq_safe } \\
\text { inefflaw*liq_vulnerable } \\
\text { inefflaw*liq_risky }\end{array}$ & $\begin{array}{l}-0.011 \\
-0.027^{*} \\
-0.03\end{array}$ & $\begin{array}{l}-0.01 \\
-0.027^{*} \\
-0.03\end{array}$ & $\begin{array}{c}-0.01 \\
-0.027^{*} \\
-0.031\end{array}$ & $\begin{array}{c}0.002 \\
-0.016 \\
-0.011\end{array}$ \\
\hline $\begin{array}{l}\text { prof_safe } \\
\text { prof_vulnerable } \\
\text { prof_risky }\end{array}$ & & & & $\begin{array}{c}0.041 \\
-0.021 \\
0.079\end{array}$ \\
\hline $\begin{array}{l}\text { inefflaw*prof_safe } \\
\text { inefflaw*prof_vulnerable } \\
\text { inefflaw*prof_risky }\end{array}$ & & & & $\begin{array}{c}-0.005 \\
0.005 \\
-0.011\end{array}$ \\
\hline $\begin{array}{l}\text { firm* quarter fe } \\
\text { bank fe } \\
N\end{array}$ & $\begin{array}{c}\text { yes } \\
\text { yes } \\
2,656,549\end{array}$ & $\begin{array}{c}\text { yes } \\
\text { yes } \\
2,656,549\end{array}$ & $\begin{array}{c}\text { yes } \\
\text { yes } \\
2,656,549\end{array}$ & $\begin{array}{c}\text { yes } \\
\text { yes } \\
1,066,145\end{array}$ \\
\hline
\end{tabular}




\section{Table 11: Interest Rates and Judicial Efficiency}

The table presents regressions of the average interest rate on judicial inefficiency, controlling for firm's characteristics. Data on interest rates are reported only by 200 banks, though they are largely representative of the population. The analysis refers to loans between banks and firms based in the same judicial court. The original data is collapsed at the firm-quarter level. inefflaw stands for the (natural $\log$ of) duration for property execution proceedings in 2007. score is the Altman synthetic indicator of firm riskiness, where 1 corresponds to low risk and 9 to high risk. More details on the variables and their sources are given in the Data Appendix. Standard errors are clustered at the firm-level. Asterisks denote significance at the $1 \%(* * *), 5 \%(* *)$ and $10 \%$ (*) level, respectively.

\begin{tabular}{|c|c|c|}
\hline & (1) & $(2)$ \\
\hline inefflaw & $0.409 * * *$ & $0.446^{* * *}$ \\
\hline \multicolumn{3}{|l|}{ score $=1$} \\
\hline score $=2$ & 0.006 & 0.045 \\
\hline score $=3$ & $0.207^{* * *}$ & $0.296 * * *$ \\
\hline score $=4$ & $0.381 * * *$ & $0.535 * * *$ \\
\hline score $=5$ & $0.798^{* * *}$ & $0.961^{* * *}$ \\
\hline score $=6$ & $1.174^{* * *}$ & $1.355^{* * *}$ \\
\hline score $=7$ & $1.467^{* * *}$ & $1.679^{* * *}$ \\
\hline score $=8$ & $1.601^{* * *}$ & $1.889^{* * *}$ \\
\hline score $=9$ & $2.098^{* * *}$ & $2.261^{* * *}$ \\
\hline $\log \left(\right.$ Total Assets $\left.s_{t-1}\right)$ & & $-0.297 * * *$ \\
\hline Leverage $_{t-1}$ & & $-0.250 * * *$ \\
\hline Age & & -0.001 \\
\hline Quarter fe & yes & yes \\
\hline$N$ & 334,090 & 284,987 \\
\hline
\end{tabular}




\section{Table 12: Robustness}

The table presents regressions of late payment as a function of a set of bank characteristics. The model allows the effect of bank variables to vary with (the natural log of) duration for property execution proceedings in 2007 (inefflaw). Late payment $(0,1)$ is equal to 1 if the firm has a loan repayment delay with the bank in the quarter; 0 if loans granted by the bank to the firm are performing in the quarter. The sample covers the period 2008q4-2013q4. The description of variables and their sources are given in the Data Appendix. Standard errors are clustered at the bank-level. Asterisks denote significance at the 1\%(***), $5 \%(* *), 10 \%(*)$ level, respectively. We do six robustness tests reported in Columns (1)-(6). Column (1): term loans only; column (2): include only the first quarter in which a loan becomes late (or overdrawn); column (3): control for four dimensions of loan terms (loan interest rate, share of loans with maturity less than one year, average ratio of collateral in accounts receivable to loan size, and average ratio of real-estate collateral to loan size); column (4): include only observations in which the bank and the lender are located in the same court jurisdiction; column (5): include bank $\times$ firm fixed effects; column (6): allow the effects of badloans to vary by region.

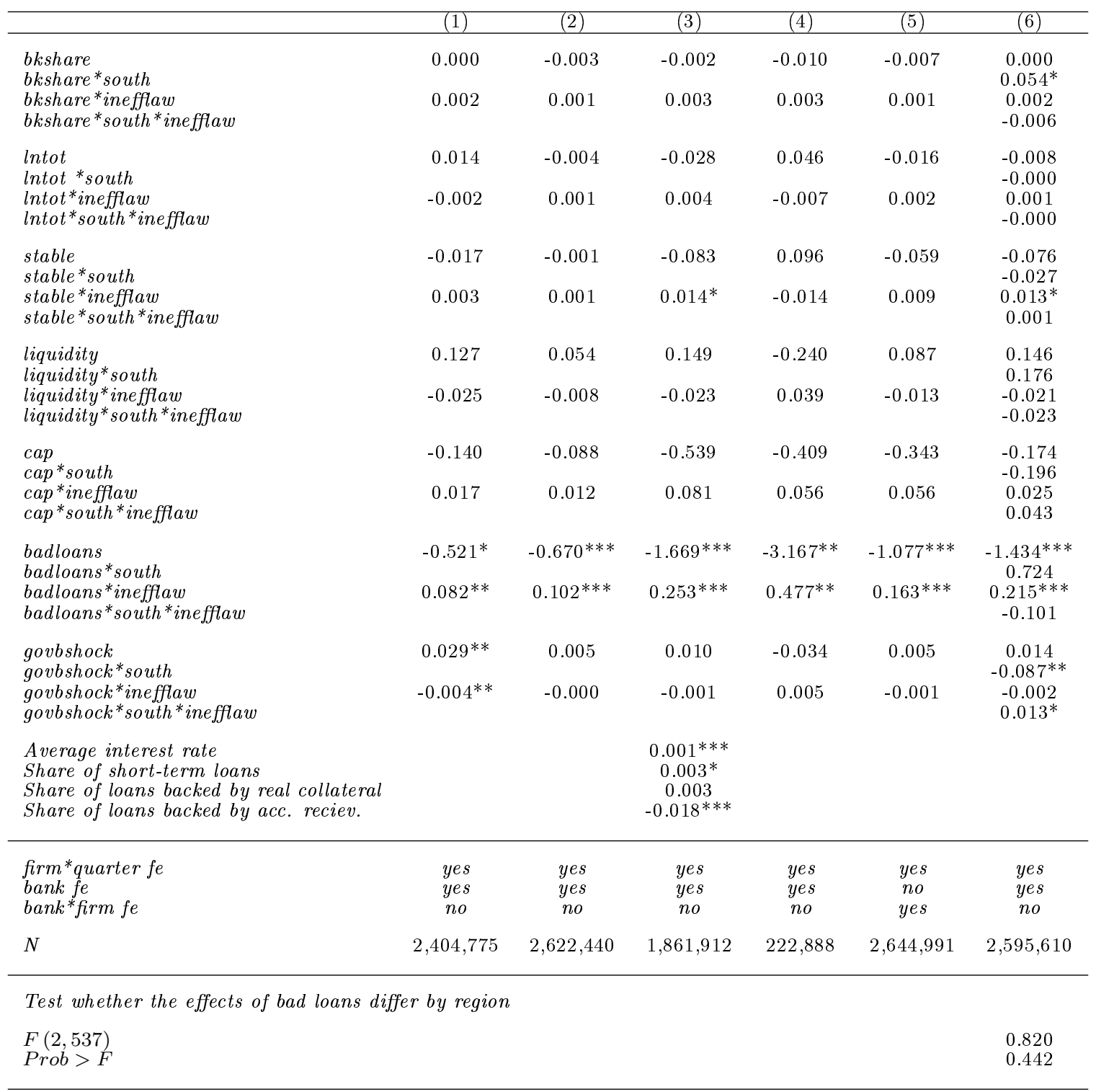


Figure 1: Late payments and other problematic loans in Italy

The figure presents statistics on problematic loans for a sample of around 32,000 industrial firms based in Italy. The description of variables and their data sources are given in the Data Appendix.

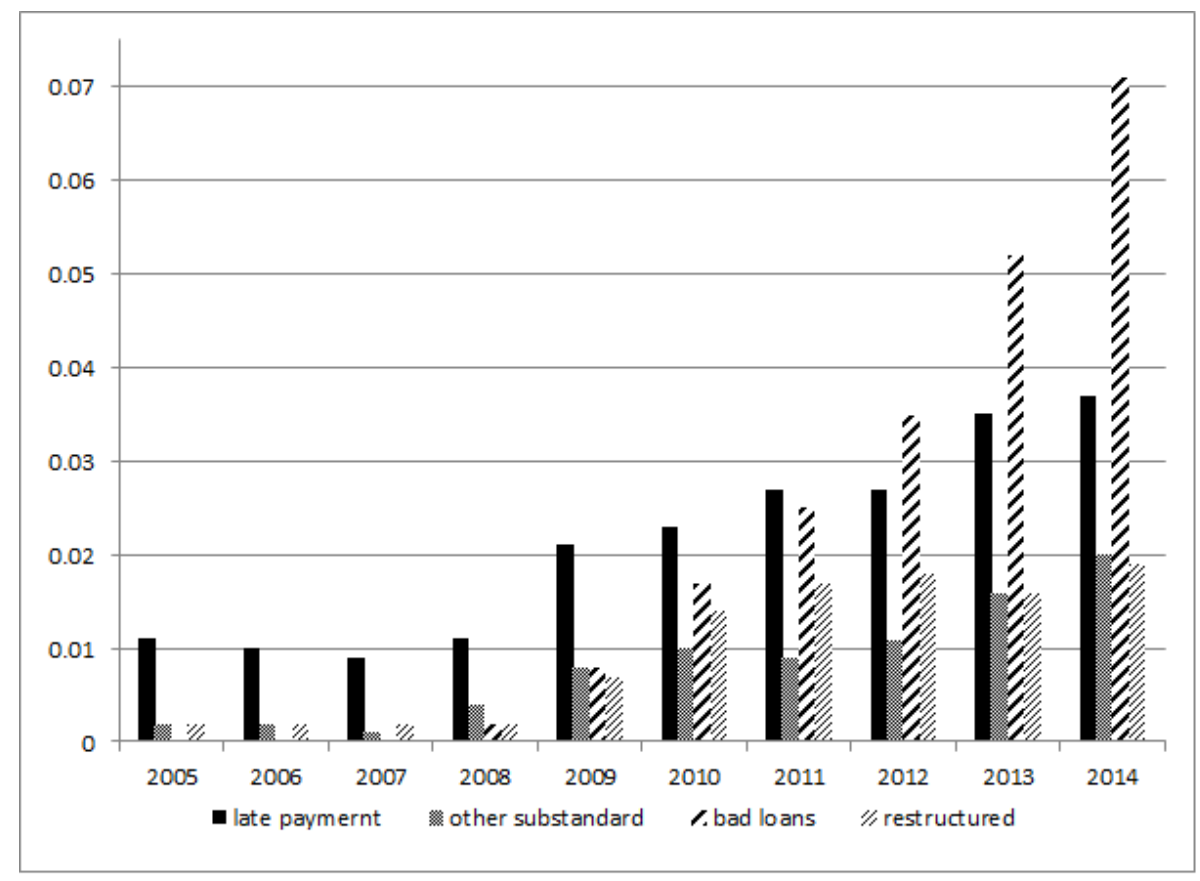


Figure 2: Judicial Efficiency in Italy: Length of Property Prosecution Proceedings across Italian Courts (2007, \# of days)

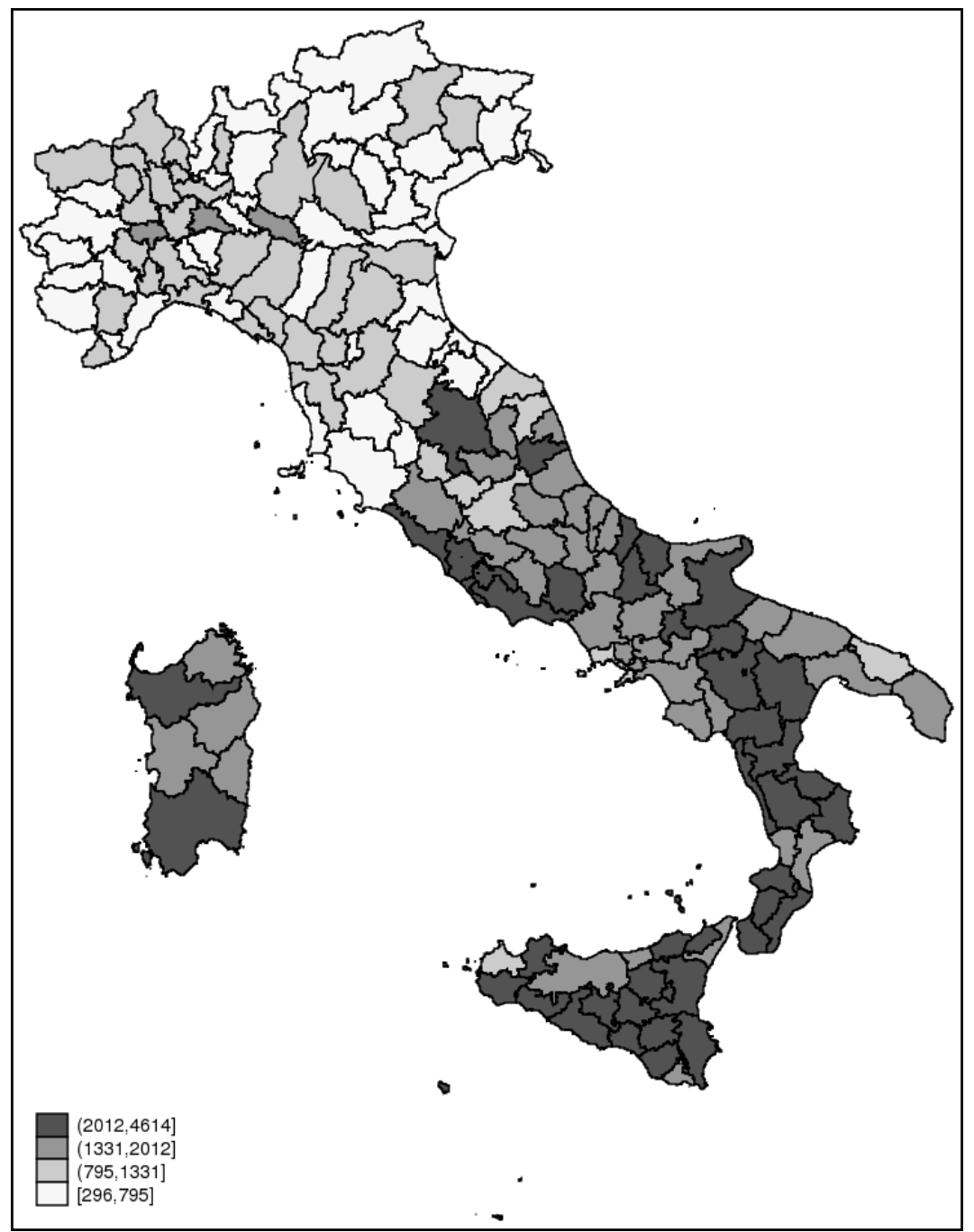


Figure 3: Marginal impacts of bad loans

The figure plots the marginal effect of bad loans on default likelihood (vertical axis) as a function of the duration for the property execution proceedings (horizontal axis, number of days)

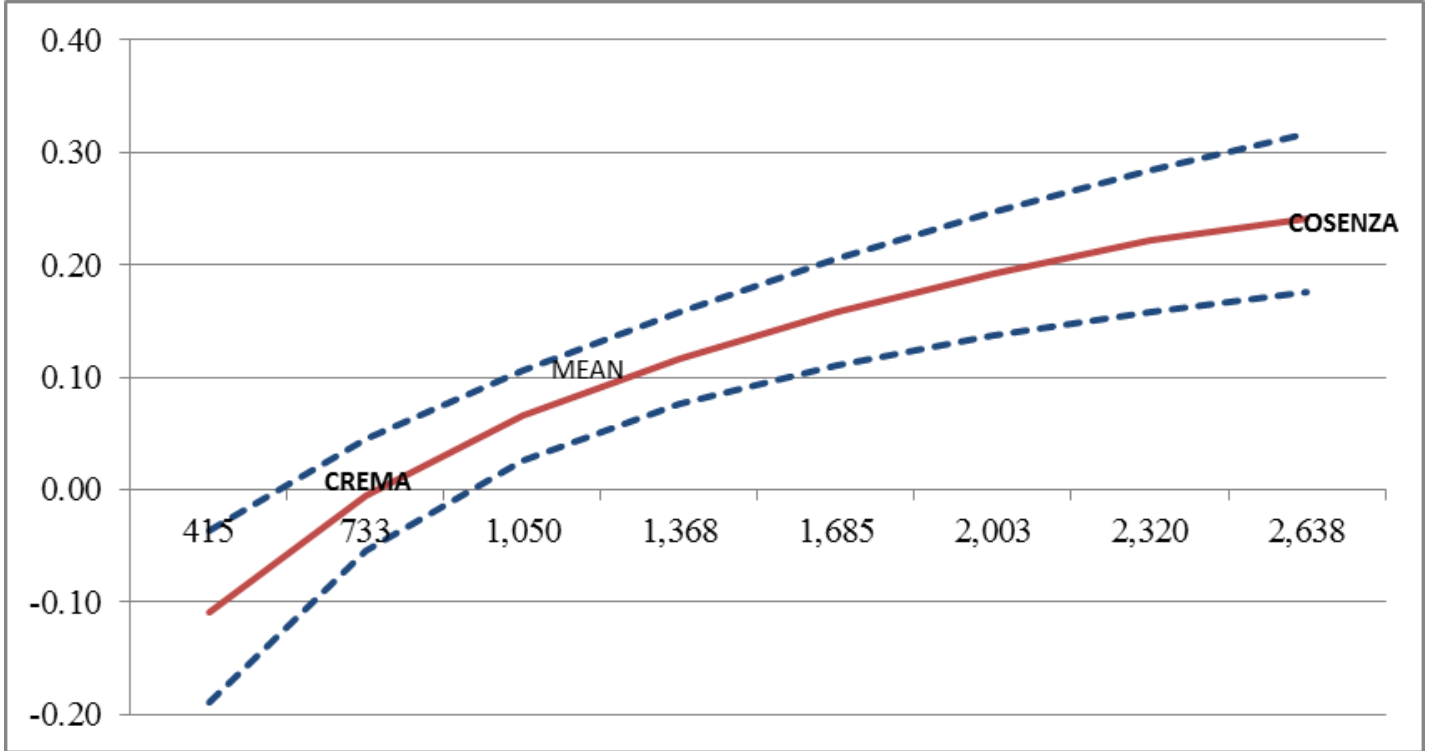

Figure 4: Marginal impacts of bad loans, by borrower risk type

The figure plots the marginal effect of bad loans on default likelihood (vertical axis) as a function of the duration for the property execution proceedings (horizontal axis, number of days), for different types of borrowers (safe, vulnerable, risky).

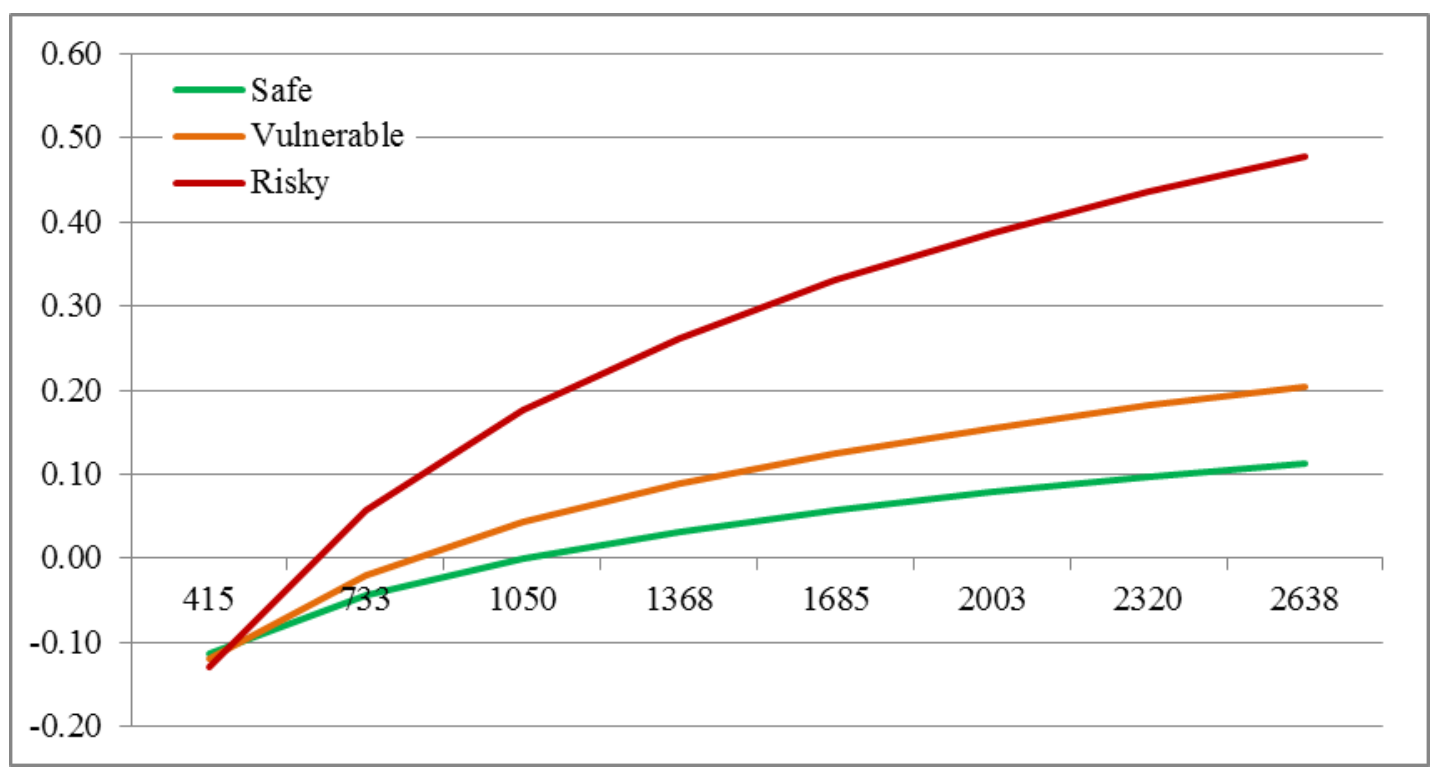


Figure 5: Marginal impacts of bad loans, safe borrowers

The figure plots the marginal effect of bad loans on default likelihood (vertical axis) as a function of the duration for the property execution proceedings (horizontal axis, number of days), for safe borrowers.

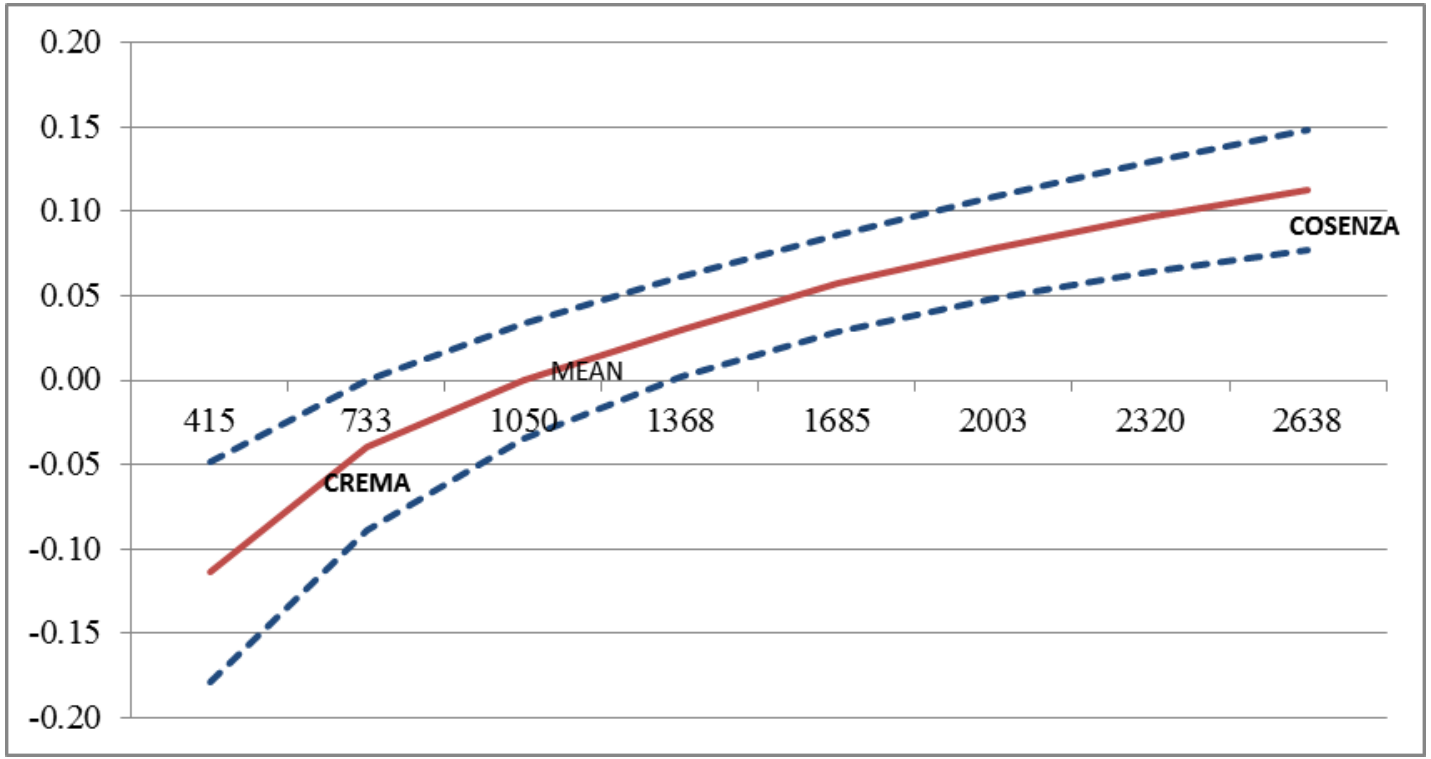

